sciendo

DOI: 10.2478/RAE-2019-0009 Review of Artistic Education no. 172019 77-99

\title{
9. ARIAS, RECITATIVES, DUETS AND VOCAL ENSEMBLES IN THE OPERA DON PASQUALE BY GAETANO DONIZETTI
}

\section{Cristina Simionescu ${ }^{20}$}

\begin{abstract}
A musical inspiration, Don Pasqule by Gaetano Donizetti offers a wealth of examples of how to capitalize on the vocal and musical potential offered by the opera show. We aim to analyze vocal scores - areas, duets, recitatives and vocal ensembles and to emphasize their musical achievement.
\end{abstract}

Key words: opera, vocals parts, comic

\section{Norina's Aria}

Norina's cavatina Quel guardo il cavaliere: We discover Norina's whimsy character from the instrumental introduction (Andante, piano) that permanently interlaces two types of rhythmic-melodic formulas (ascending and descending) made by the combination between high and very low values of the notes (one measure sextolet), and the accents on weak measure. E.g. 1 (G. Donizetti - Don Pasquale, Edizione Ricordi, Milano, 2006, Act I, Scene IV, Norina's cavatina: Quel guardo il cavaliere, p. 40, ms. 1-8):

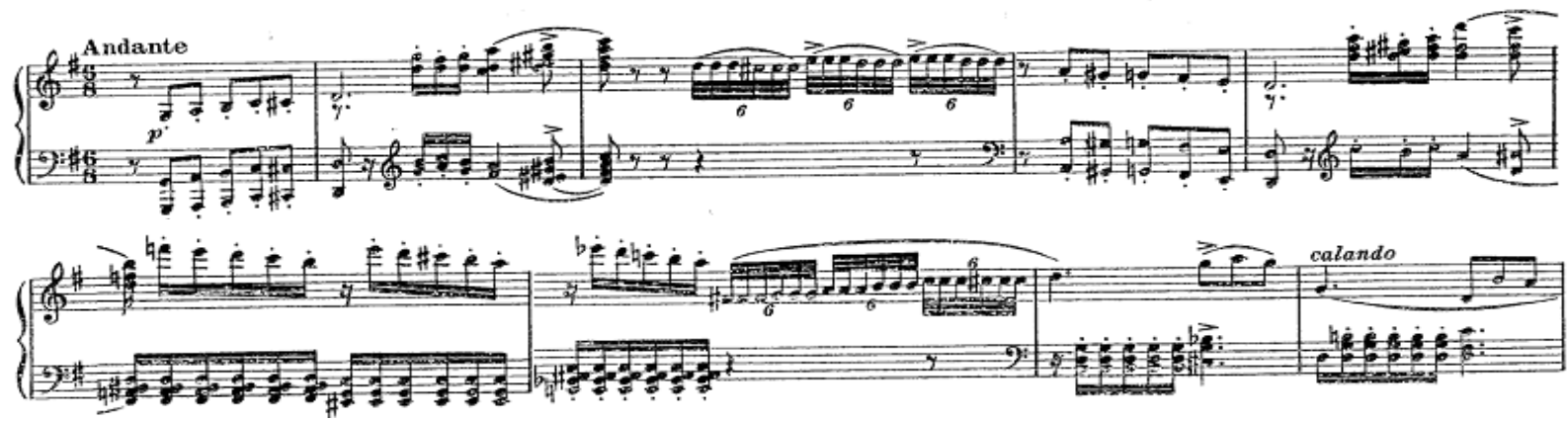

The aria is organized in two parts: a first recitative part - which by the melodics and morphological structure can be considered the slow part $(\boldsymbol{A})$ and a $\boldsymbol{B}$ - the aria itself. Norina reads aloud from a book and even from the first reply (Quel guardo il cavaliere ${ }^{2 l}$ ) we discover persiflage and disinterest for the subject of the novel. The melodic line has a gradually ascending drawing, followed by a descending leap then replaced with various descending fioritura, reminiscent of the musical style of the Middle Ages troubadours' period (where the action of the novel takes place). E.g. 2 (G. Donizetti - Don Pasquale, Edizione Ricordi, Milano, 2006, Act I, Scene IV, Norina's cavatina: Quel guardo il cavaliere, p. 40, ms. 10-27):

\footnotetext{
20 Associate Professor PhD., "George Enescu" National University of Arts, Iaşi, România, email: crystina.simionescu@yahoo.com

${ }^{21}$ That look of the knight(t.a.Cr.S.A.).
} 


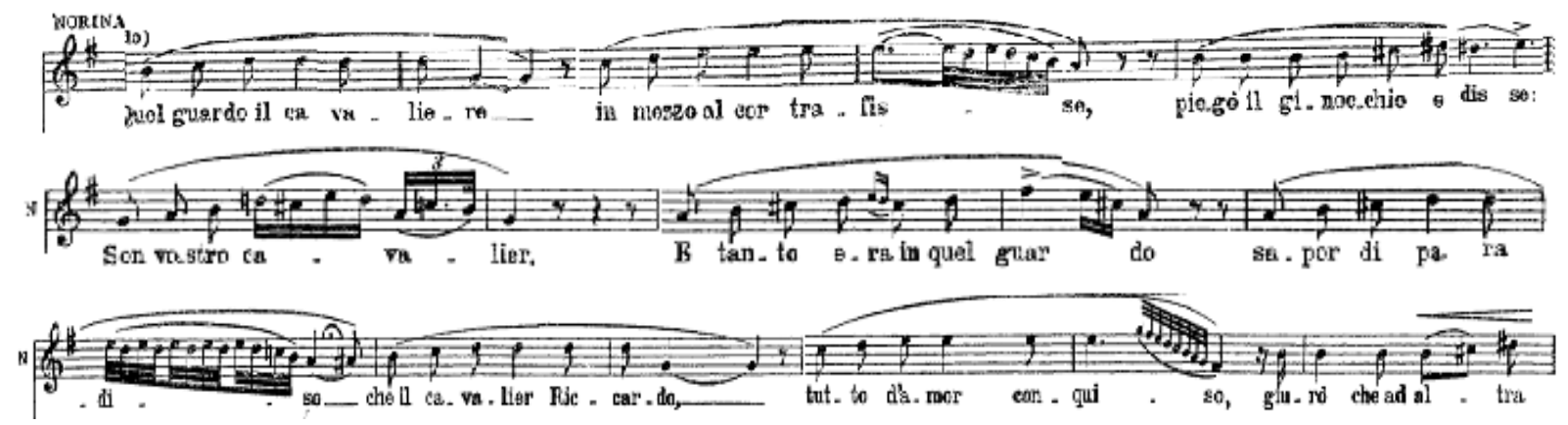

The descending roulades show the ironic attitude to the heroine of the novel, but the phrases keep their lyrical character; The tauntin gritartando (on cavalier) is followed by a very romantic exposure (e tanto era in quel guardo ${ }^{22}$ ), and the crescendo in the phrase giurò che ad altra mai ${ }^{23}$ ends with $s f p$ (the boredom given by the subject of the book). The emphasis on the second syllable of the word disse $e^{24}$ is contrary to the musical rules and prosody of the Italian language, highlighting the mocking sense of the heroine's oath (Son vostro cavalier! ${ }^{25}$ ). E.g. 3 (G. Donizetti - Don Pasquale, Edizione Ricordi, Milano, 2006, Act I, Scene IV, Norina's cavatina: Quel guardo il cavaliere, p. 41, ms. 16-18):

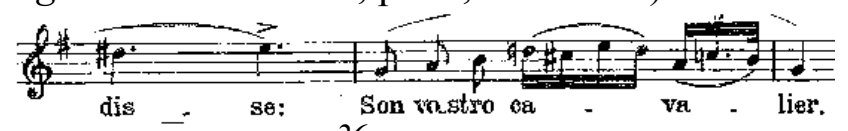

as is the case with the word guardo $^{26}$ (as a reaction to comparison with sapor di paradiso $^{27}$ ). E.g. 4 (G. Donizetti - Don Pasquale, Edizione Ricordi, Milano, 2006, Act I, Scene IV, Norina's cavatina: Quel guardo il cavaliere, p. 41, ms. 20-21):

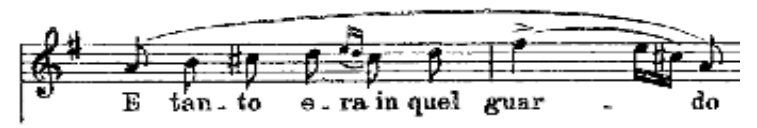

Fermata for a while announces the change of attitude, and the laughing laughter anticipates the second part of the aria (where Norina makes her selfportrait). A short orchestral introduction describes the capricious unexpected, somewhat unscrupulous and nonconformist of the young female (appoggiatura, punctuated values and melodically broken course). E.g. 5 (G. Donizetti - Don Pasquale, Edizione Ricordi, Milano, 2006, Act I, Scene IV, Norina's cavatina: Quel guardo il cavaliere, p. 42, ms. 32-42):

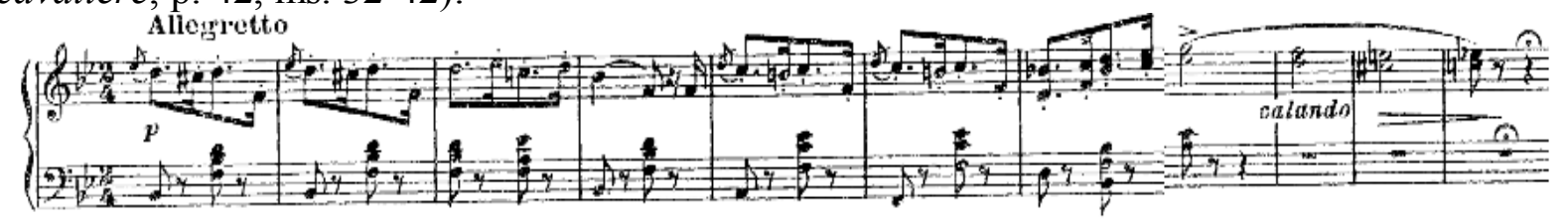

Norina is perfectly aware that besides exuberance, she also has a great flair. The melodic line loaded with appoggiatura and descending melodic leaps suggestively describes the changes of mood that she can co-ordinate if she

\footnotetext{
${ }^{22}$ And it was so much in that look (t.a.Cr.S.A).

${ }^{23}$ He swears he will never think of another (t.a.Cr.S.A).

${ }^{24}$ Says (it.).

${ }^{25}$ I'm your knight (t.a.Cr.S.A).

${ }^{26}$ Look (It.).

${ }^{27}$ With a paradise flavor (t.a.Cr.S.A).
} 
forces herself (d'un breve sorisetto ${ }^{28}$, menzognera lagrima ${ }^{29}$, subito languor ${ }^{30}$ ). Rallentando on the reply $i$ cori lento foco ${ }^{31}$ shows how patient she may be if she proposes herself to seduce someone and the return to a tempo (d'un breve sorrisetto) brings a new sudden change of character, like a blast of joy. The short melodic motifs conosco $i$ mille modi dell'amorose frodi, $i$ vezzi e l'arti facili $^{32}$ come to complete the self-portrait and they can be highlighted by the vocal expressiveness and varied timbral coloring. E.g. 6 (G. Donizetti - Don Pasquale, Edizione Ricordi, Milano, 2006, Act I, Scene IV, Norina's cavatina: Quel guardo il cavaliere, p. 42, ms. 59-64):

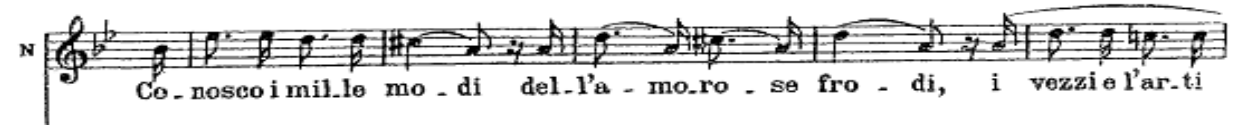

The pride and safety on the qualities she possesses in the art of seduction are revealed by two roulades (l'effetto ${ }^{33}$ and per inspirare amor ${ }^{34}$ ): E.g. 7 (G. Donizetti - Don Pasquale, Edizione Ricordi, Milano, 2006, Act I, Scene IV, Norina's cavatina: Quel guardo il cavaliere, p. 43, ms. 81-87):

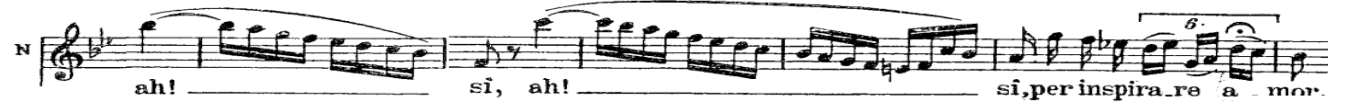

An orchestral passage with repeated notes makes the transition to the rhythmic-melodic fragment with a recitative role (Più mosso) which continues the description of the heroine virtues: ho testa bizzarra, son pronta, vivace ${ }^{35}$. Structures on triplets completed by indications con forza and rallentando reveal two other paradoxical manifestations of Norina: se monto in furore, di rado sto al segno, ma in riso lo sdegno fo presto a cangiar. Ho testa bizzara, ma core eccellente $^{36}$. E.g. 8 (G. Donizetti - Don Pasquale, Edizione Ricordi, Milano, 2006, Act I, Scene IV, Norina's cavatina: Quel guardo il cavaliere, p. 44, ms. 94-103):

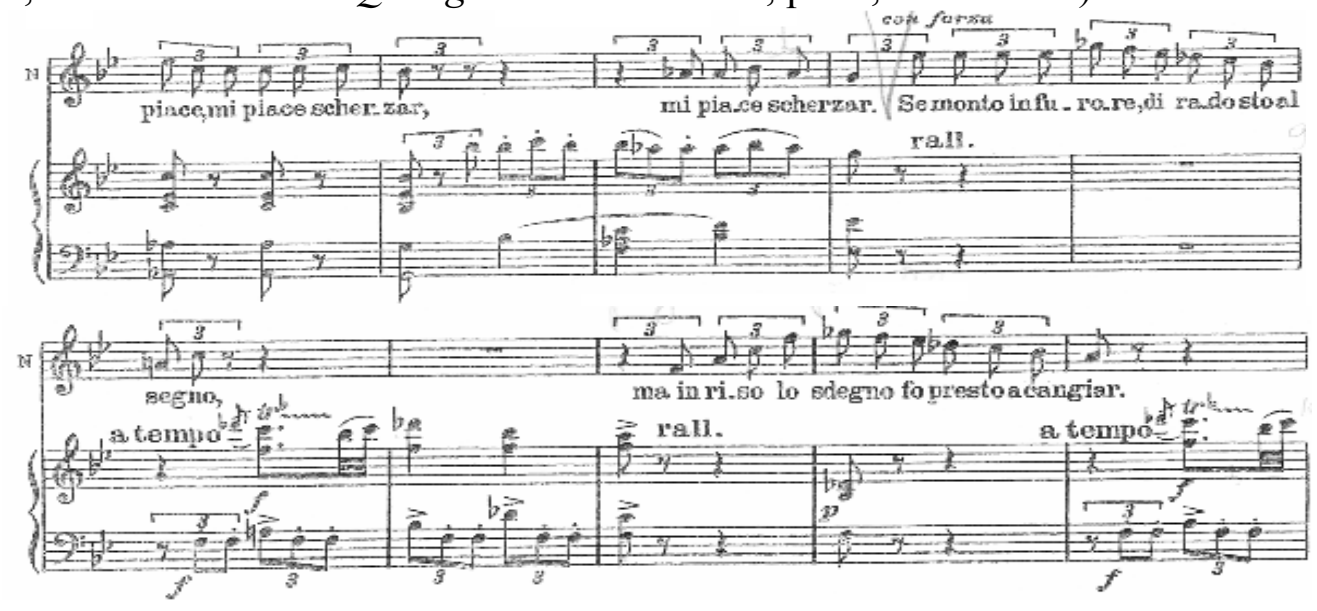

\footnotetext{
${ }^{28}$ A little smile (t.a.Cr.S.A).

${ }^{29}$ A lying tear (t.a.Cr.S.A).

${ }^{30}$ A sudden exhaustion(t.a.Cr.S.A).

${ }^{31}$ Hearts burning slowly (the translation from the Italian language belongs to the author).

${ }^{32}$ I know thousands of ways to corrupt lovers, by caresses and light art of love (t.a.Cr.S.A.).

${ }^{33}$ The effect (It.).

${ }^{34}$ To inspire love (t.a.Cr.S.A.).

${ }^{35}$ I have a strange mind, I'm prompt, spirited(t.a.Cr.S.A.).

${ }^{36}$ If I get mad it's not good, but the laughter comes back and I change quickly. I have a quite bizarre mind, but the soul is very good (t.a.Cr.S.A.).
} 
The seven measures of quaver are very expressive and brilliant, as a crowning of feelings of gratitude, pleasure and satisfaction to the personal qualities and virtues that distinguish it from the rest of the world. E.g. 9 (G. Donizetti - Don Pasquale, Edizione Ricordi, Milano, 2006, Act I, Scene IV, Norina's cavatina: Quel guardo il cavaliere, p. 44, ms. 114-121):

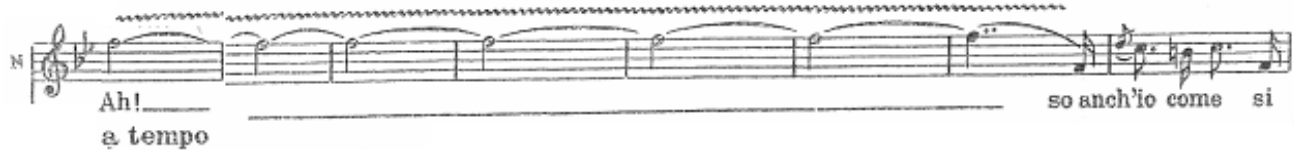

On this quaver the orchestra sings the first motif of the original sentence (son anch'io la virtu magica), then the melodic line returns to the voice and repeats the aria beginning identically. The final beat is quite broad, including roulades, fioritura and rhythmic-melodic structures in triplets. E.g. 10 (G. Donizetti - Don Pasquale, Edizione Ricordi, Milano, 2006, Act I, Scene IV, Norina's cavatina: Quel guardo il cavaliere, p. 46, ms. 160-192):

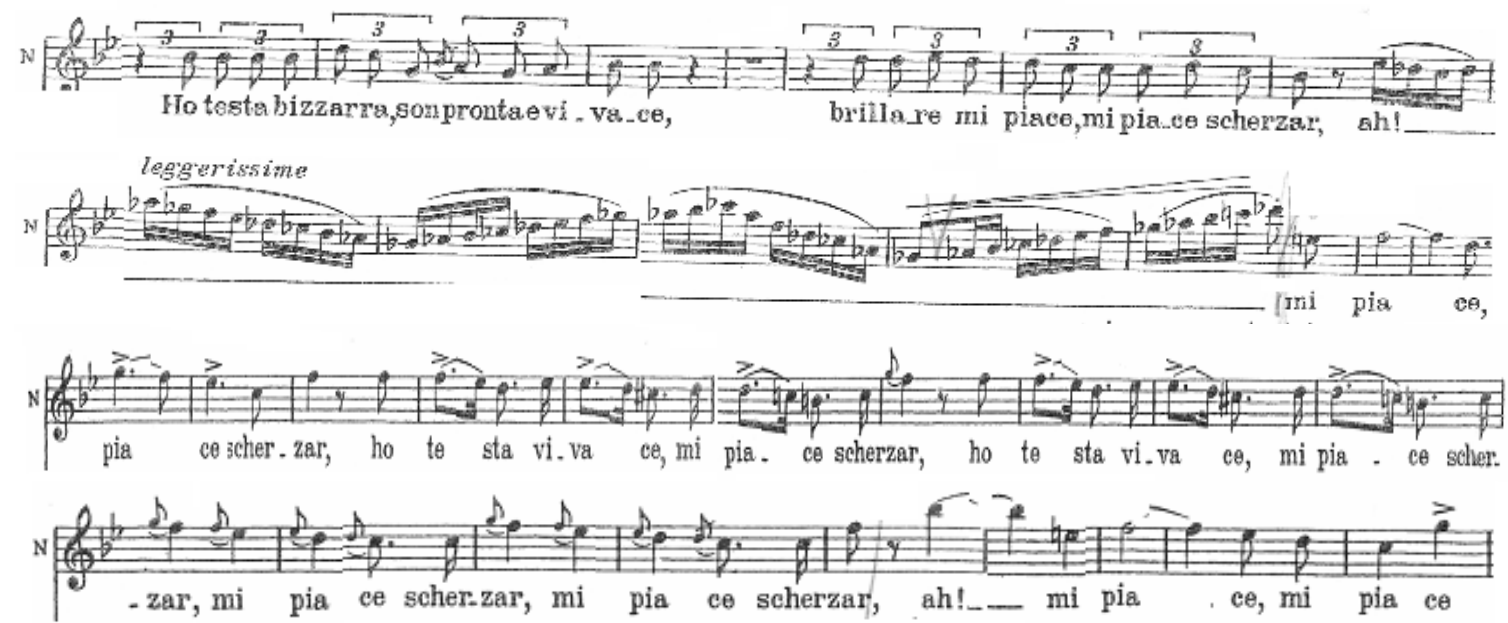

The tonal play is built according to the exhibiting needs of the character, and the orchestra plays an accompaniment role (rarely replaced by a solo or equal voice partner). E.g. 11 (G. Donizetti - Don Pasquale, Edizione Ricordi, Milano, 2006, Act I, Scene IV, Norina's cavatina: Quel guardo il cavaliere, p. 43, ms. 68-76):

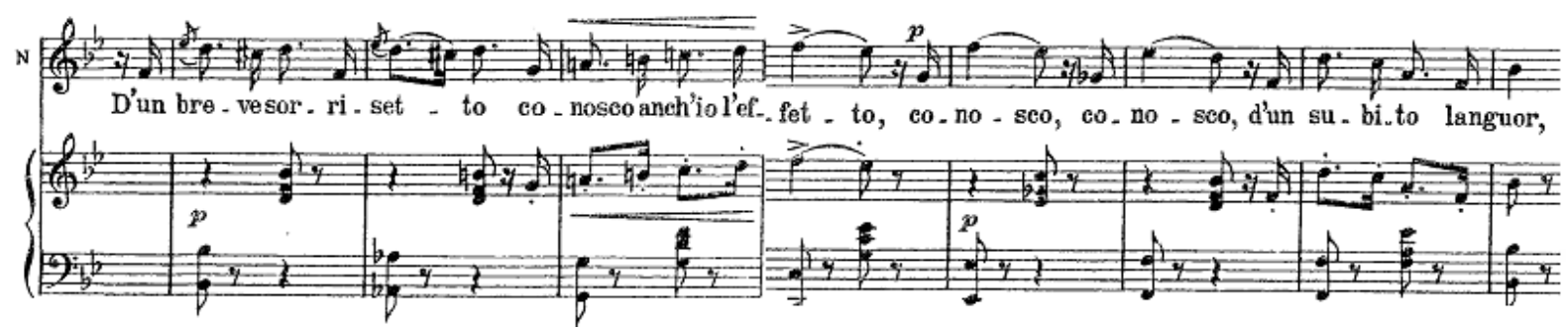

Colored quads are a "bonus" and not an integral part of the aria, and can only be used previous show conductor and stage director's approval.

\section{Recitatives}

E il Dottor non si vede! - Norina's monologue before the duet with Malatesta is an indisputable proof of Donizetti's science in making recitatives very close to the intonations of the spoken language, the accompaniment being only a long, harmonious support. E.g. 12 (G. Donizetti - Don Pasquale, Edizione 
Ricordi, Milano, 2006, Act I, Recitativo e Duetto Finale I: E il Dottor non si vede!, p. 48, ms. $1-7)$ :

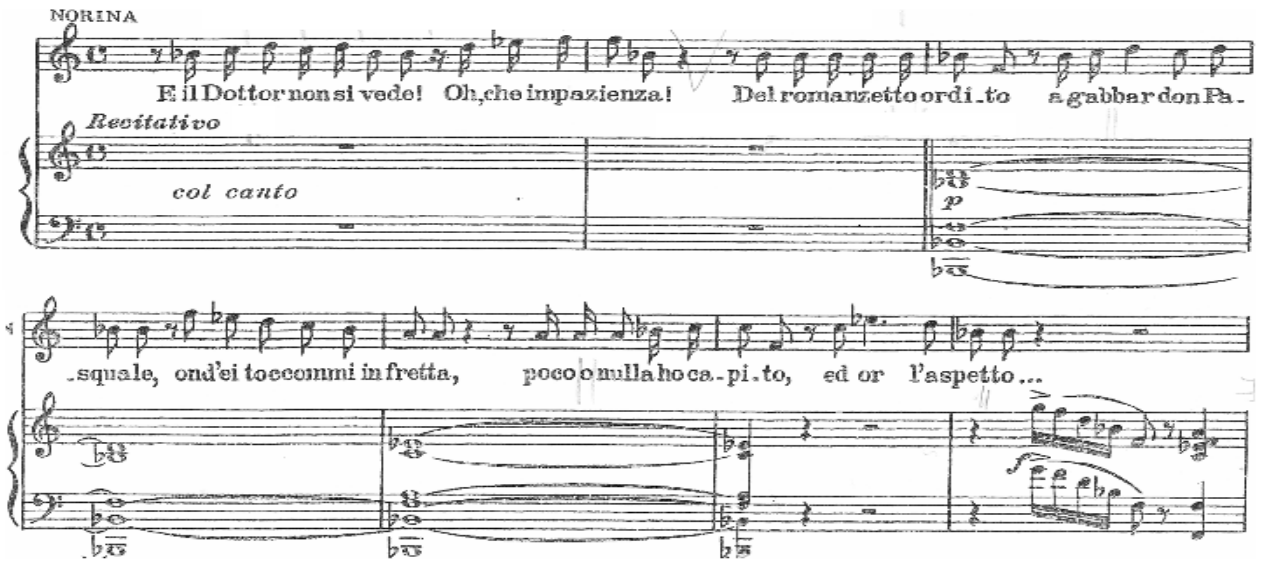

The doctor's appearance brings accompaniment changes, revealing the thoughts and reactions of the two characters. (The letter Norina received from Ernesto is simply recited by Malatesta, without any accompaniment). Malatesta presents a detailed description of the stratagem he proposes, but Norina interrupts him by saying without hesitation that the instructions are very clear to her and that she is ready to act, and we will discover in Norina's melodics a combination of pride, maximum self-confidence and desire of vengeance. E.g. 13 (G. Donizetti - Don Pasquale, Edizione Ricordi, Milano, 2006, Act I, Recitativo e Duetto Finale I: E il Dottor non si vede!, p. 48, ms. 1-7):

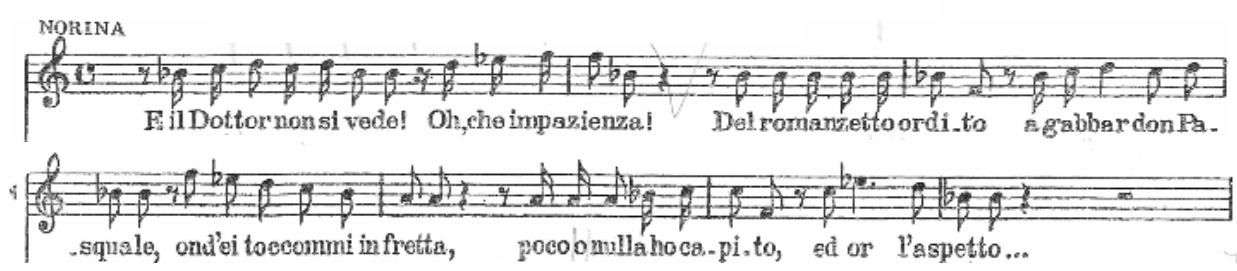

Non abbiate paura: After the triplet (Act II), the three characters start sounding out about the marriage (recitative). So, Pasquale and confonde in inchini $^{37}$, Malatesta tells Sofronia not to be afraid of his old friend, who is also asking her to greet him. Norina's response is comic both by scenic indication ( $\mathrm{fa}$ una riverenza senza guardare Don Pasquale ${ }^{38}$ ), as well as through the melodic line (descendant triplet rendering the "fear" of being near a stranger). E.g. 14 (G. Donizetti - Don Pasquale, Edizione Ricordi, Milano, 2006, Act II, Scena e Quartetto Finale II: Non abbiate paura, p. 85, ms. 6-8):

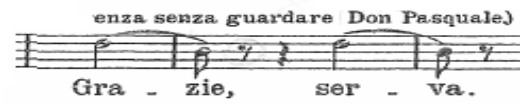

Three asides clearly reveal the thoughts of the characters: Pasquale's sincere joy (who believes that Sofronia is the ideal wife), Malatesta's satisfaction (knowing that the plan will succeed) and Norina's disdain (oh, che baggiano! ${ }^{39}$ ). Malatesta suggests the old man should have a dialogue with Sofronia in order to see if they have common tastes and principles. The girl's response to the old

\footnotetext{
${ }^{37}$ He tangles in his bowels (t.a.Cr.S.A.).

${ }^{38}$ He makes a reverence without looking at Don Pasquale (t.a.Cr.S.A.).

${ }^{39}$ Oh, what a pumpkin head! (t.a.Cr.S.A.).
} 
man's interrogation is gentle, polite, shy and patient, relating about the life she lived in the monastery (always alone, with nothing special to do), saying she did not know what theater was and that she had no curiosity in this sense, enumerating the domestic activities acquired in the monastery and all these revelations permanently conquer Pasquale, extremely impatient in anticipation of the happy event. Parlando used in the recitative is monotonous (as is the nature of Sofronia), the rhythm is unitary (eighths notes, the semiquavers appear only when she states that she does not want to know what the theater is or when she lists the activities carried out at the monastery: cucire, ricamar, far la calzetta, badare alla cucina ${ }^{40}$ ), and the accompaniment is almost inexistent (short harmonic support chords). E.g. 15 (G. Donizetti - Don Pasquale, Edizione Ricordi, Milano, 2006, Act II, Scena e Quartetto Finale II: Non abbiate paura, p. 87, ms. 2839):

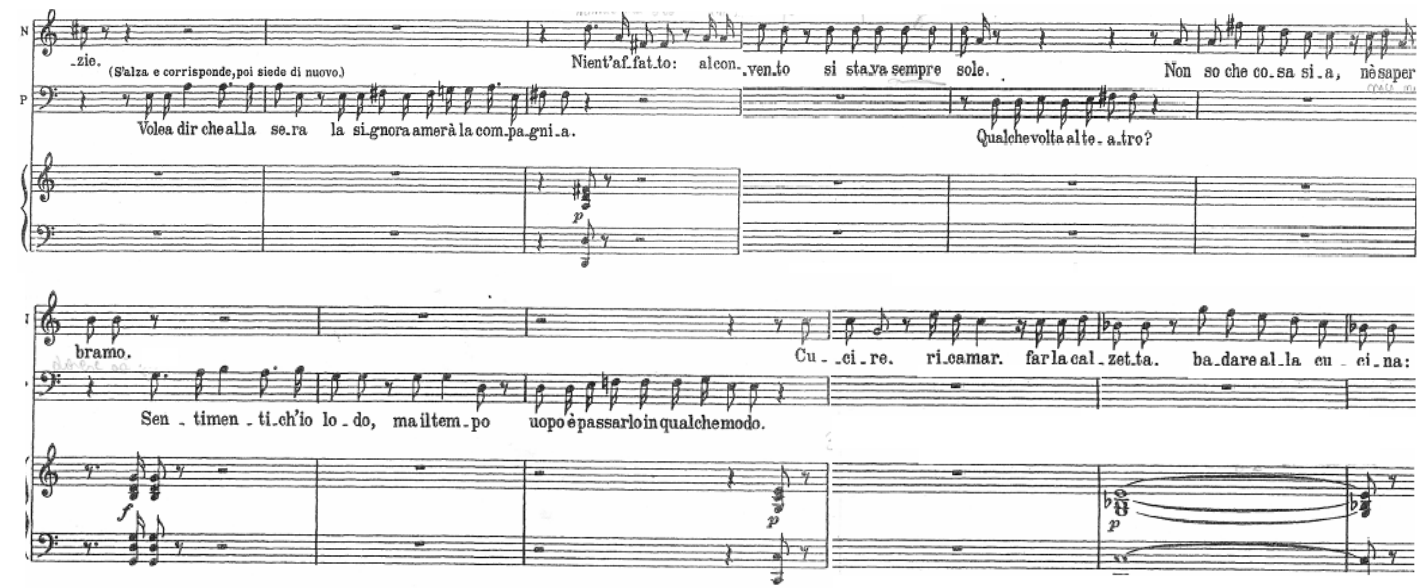

Satisfied with the answers he received, Pasquale would like to see Sofronia's face, Malatesta asks his sister to take out her veil; embarassed, the girl affirms (a melodic line highlighting shame): non oso in faccia a an uom $^{41}$. To prove the submission of his sister, Malatesta orders her to uncover her face immediately and the girl obeys immediately. The effect of explosion triggered in Pasquale's heart by the beautiful face is rendered by Allegro with brief phrases, interrupted by optimi breaks (gaspy breathing), semiquaver notes (precipitation of the love-stricken old man) and orchestration in tremolo. Asked if she liked the gentleman in front of her, Sofronia continues playing her role of an ingenuous and replies avery short, shy $\mathrm{Si}$, followed by a sarcastic aside (sei pur il gran babbione! $!^{42}$ ). E.g. 16 (G. Donizetti - Don Pasquale, Edizione Ricordi, Milano, 2006, Act II, Scena e Quartetto Finale II: Non abbiate paura, p. 90, ms. 70-75):

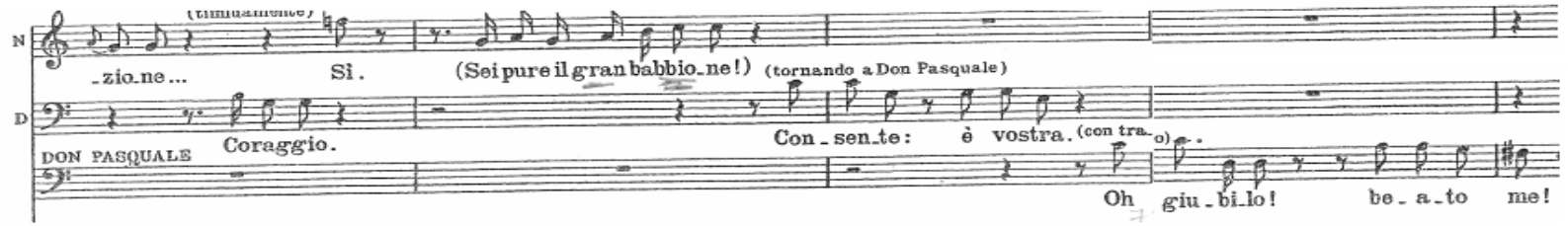

\footnotetext{
${ }^{40}$ I sew, I embroider, I braid socks, I cook and clean(t.a.Cr.S.A.).

${ }^{41}$ This is not appropriate in front of a man(t.a.Cr.S.A.).

${ }^{42}$ You're such a baboon! (t.a.Cr.S.A.).
} 
Jubilating happiness, Pasquale thinks he was blessed with such a perfect wife, while the new aside of Norina sounds threatening: Te n'avvedrai fra poco! $!^{43}$.

\section{Duets and vocal ensembles}

The Malatesta -Norina- duet: Pronta io son is built around the stratagem proposed by the doctor, referring to the behavior Norina must appropriate in order to become Sofronia in an attempt to conquer Don Pasquale. The duet has four large and recitative parts: the first part - $\boldsymbol{A}$ - introductory sentence Norina, followed by two bipodic periods $(\boldsymbol{A}$ and $\boldsymbol{A} \boldsymbol{1})$ and a conclusion with a cadential role, continued by Malatesta on the same structure (introductory phrase, two periods $\boldsymbol{A}^{\prime}$ and $\boldsymbol{A} \boldsymbol{1}^{\prime}$ and cadential phrase) and follows a linking bridge melodically exposed by Norina. The second part (Norina proves different ways of shaping the character of Sofronia) is structured in four bipodic periods: $\boldsymbol{B}, \boldsymbol{B} \boldsymbol{v}$, $\boldsymbol{B} v 1, \boldsymbol{B} \boldsymbol{v} 2$ and a linking bridge (recitative) to the third part - with two periods $\boldsymbol{C}$ (bipodic) and $\boldsymbol{D}$ (four phrases) followed by an outer enlargement with a cadential role (these two periods are identical, being separated by a recitative fragment with an interlude role). The last part is the duet conclusion, as the characters greatly amuse themselves about the show to come. The first sequence (Maestoso) is a somewhat hilarious presentation of the marcial character of the "confrontation" between Sofronia and Pasquale. Norina's contradictory feelings (in love and eager for vengeance) are musically transposed by contrasting shades (forte-piano), and, from a melodical perspective, the determination of the girl ready to fight is carried out without stridence or screams, on an anacrusis accompaniment. E.g. 17 (G. Donizetti - Don Pasquale, Edizione Ricordi, Milano, 2006, act I, Recitativo e Duetto Finale I: Pronta io son, p. 52, ms. 51-56):

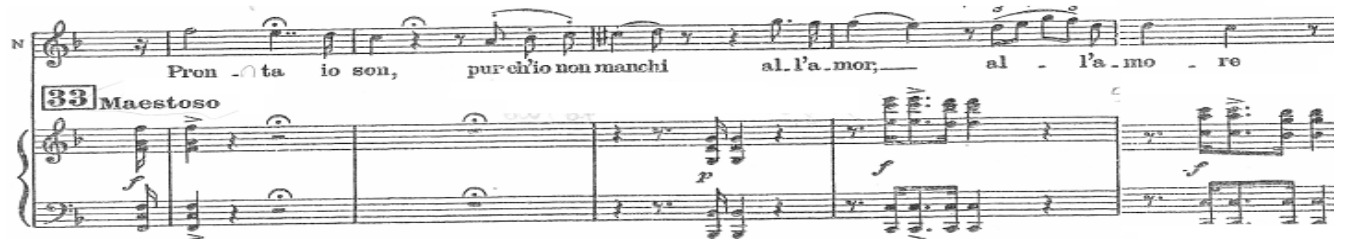

The musical discourse is built on the phrase faro imbrogli, faro scene, so ben io quel ch'io da $\mathrm{far}^{44}$ by a repetitive rhythmic-melodic cell sequenced on different stages; from a rhythmic point of view, we notice a major change with the occurrence of small values (sixteenth with a point followed by a thirtysecond and triolets on half a measure). E.g. 18 (G. Donizetti - Don Pasquale, Edizione Ricordi, Milano, 2006, Act I, Recitativo e Duetto Finale I: Pronta io son, p. 52-53, ms. 5766):

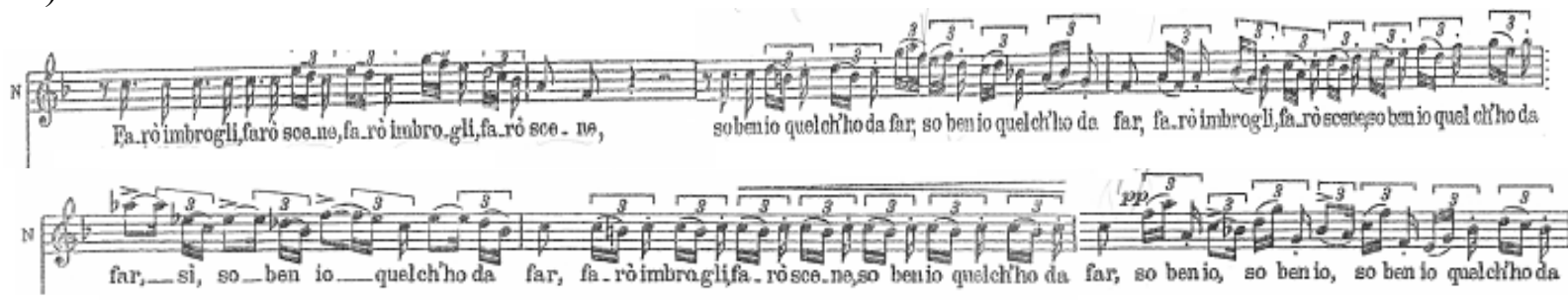

${ }^{43}$ Just wait and see! (t.a.Cr.S.A.).

${ }^{44}$ I'm going to cause trouble, I'm going to make scenes, I know very well what I have to do (t.a.Cr.S.A.). 


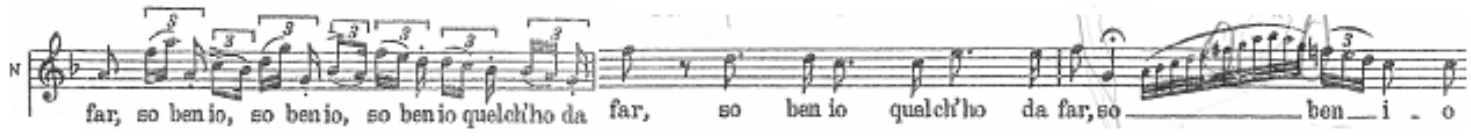

The end of Norina's exposition has a cadential effect, with different melodic passages exposing self-confidence on the same text. E.g. 19 (G. Donizetti - Don Pasquale, Edizione Ricordi, Milano, 2006, Act I, Recitativo e Duetto Finale I: Pronta io son, p. 53, ms. 66-67):

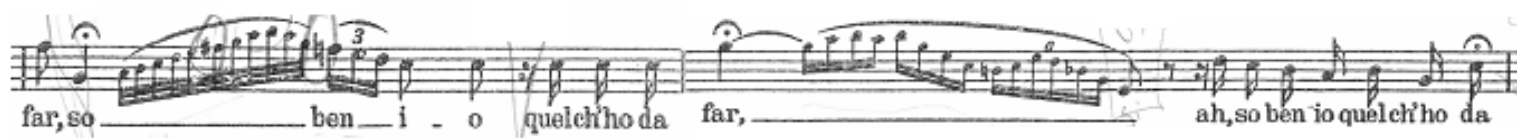

The accompaniment proves to be a novelty for the Donizettian discourse: on a ostinato bass sextoles, the violin melodic line (staccato) has an emphasis on the second half of the second and third measure. E.g. 20 (G. Donizetti - Don Pasquale, Edizione Ricordi, Milano, 2006, Act I, Recitativo e Duetto Finale I: Pronta io son, p. 52, ms. 57-58):

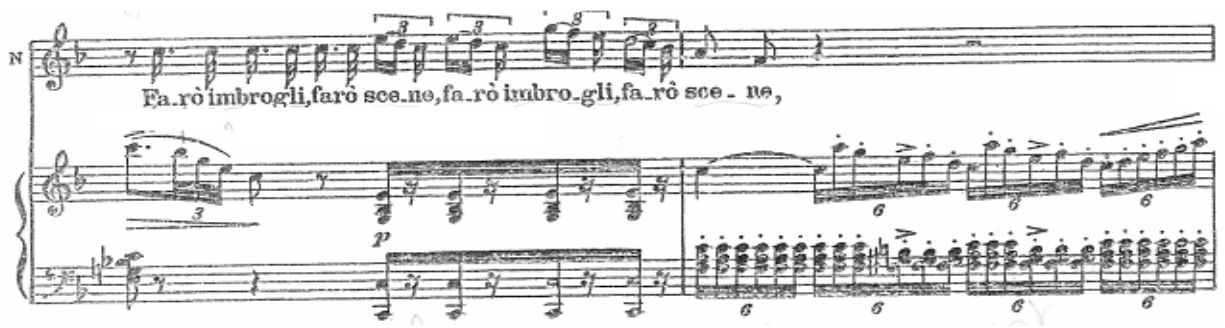

The rhythmic variations in orchestration continue by overlapping the binary and ternary rhythms and the appearance of syncope for half a measure. E.g. 21 (G. Donizetti - Don Pasquale, Edizione Ricordi, Milano, 2006, Act I, Recitativo e Duetto Finale I: Pronta io son, p. 53, ms. 61-62):

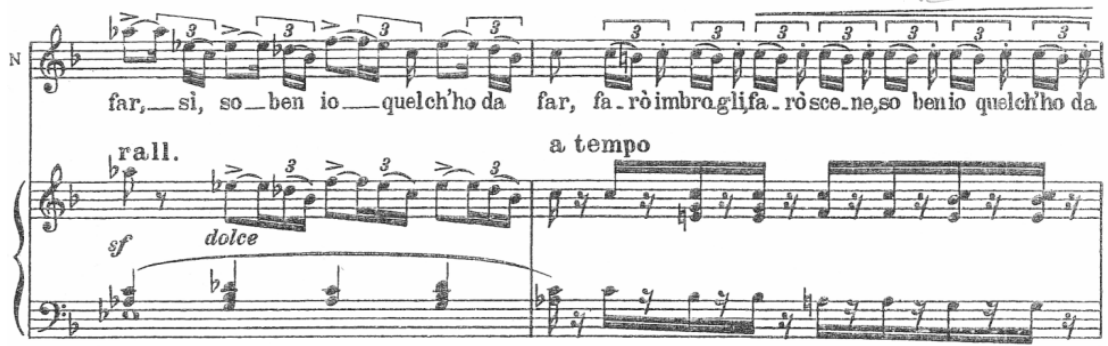

The contrasting dynamics (the transition from the preparatory orchestral fragment to the piano is made by crescendo for voice, then diminuendo) suggest Nora's tenacity, impatience and desire for revenge. Her great quality of selfcontrol over behavioral change is underlined by crescendo up to sforzando (on the word lighthouse) that immediately calms down and returns to a reduced tone (dolce). The same melodic course, rhythm and nuances are taken over by Malatesta in his discourse, which proves that although the text is different, the purpose of the two characters is common and thus the alliance is between them is sanctified. In the second part of the Malatesta duet, there is an education course for the future Sofronia, and we will discover Norina's wicked nature (plastically emphasized by the composer), seriously experimenting with different variants of attitude that she can perfectly interpret to trick Pasquale. Malatesta opts for the variant of a young, submissive, young woman, just 
coming out of the monastery. The meanings of the melodic lines perfectly reproduce the expression of behavioral attitudes listed by Norina: mi volete fiera ${ }^{45}$ - ascending to the fourth, mi volete mesta ${ }^{46}$ - ascending sixth leap followed by a descending leap (annoyance) ho da piangere ${ }^{47}$ - ascending leap of sixth followed by a descending rhythm (sighs), ho gridare ${ }^{48}$ - in the acute register with ascending third leap followed by descending octave leap (screams). E.g. 22 (G. Donizetti - Don Pasquale, Edizione Ricordi, Milano, 2006, Act I, Recitativo e Duetto Finale I: Pronta io son, p. 56, ms. 92-97):
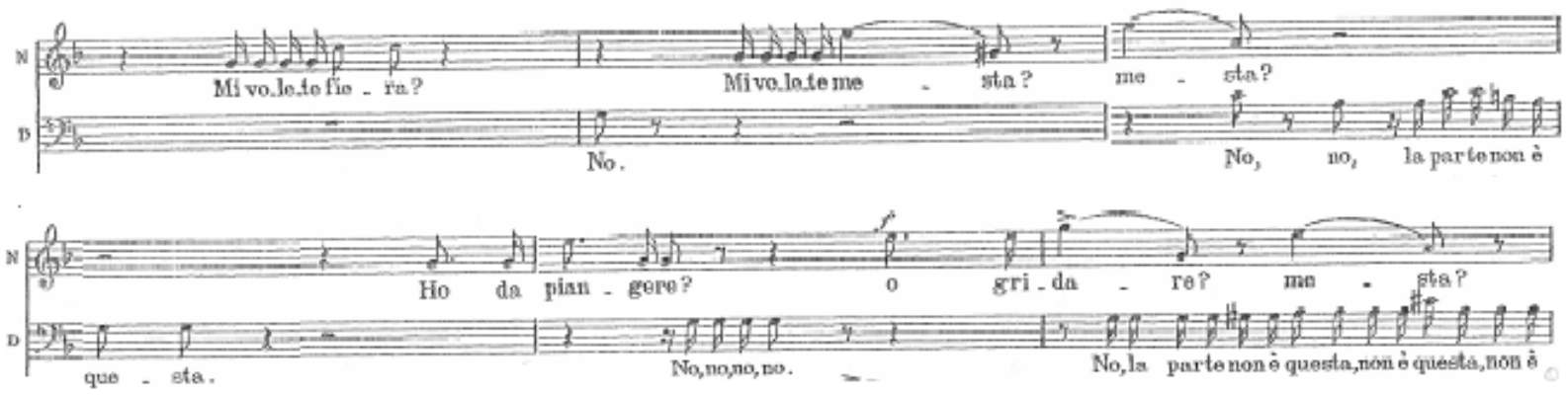

Malatesta wants for the old man: la semplicetta ${ }^{49}$. Norina can interpret this role with great easiness (we will use a great variety of vocal colors), which causes her to express her joy through long distance leaps. E.g. 23 (G. Donizetti Don Pasquale, Edizione Ricordi, Milano, 2006, Act I, Recitativo e Duetto Finale I: Pronta io son, p. 57, ms. 1001-103):

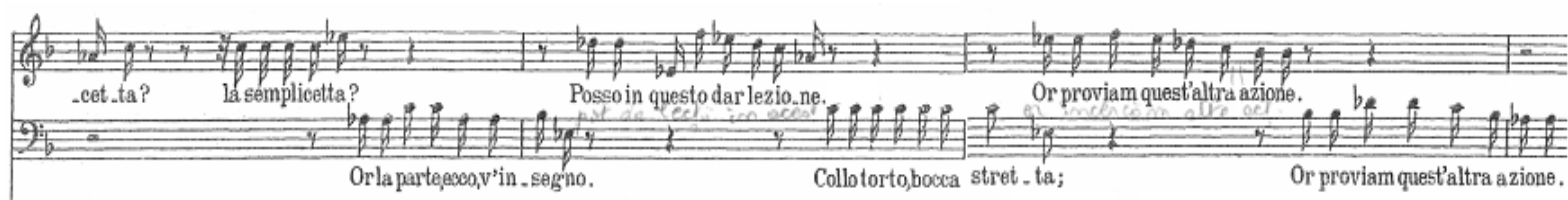

The eighth and fourths in Norina's melodic line contrast with the sixteenths of Malatesta's speech, expressing the joy and satisfaction of having a receptive and intelligent "student". Entering Norina's play, Malatesta conducts a fake dialogue with her, based on rhythmic-melodic elements taken from one interpreter to another, or overlapped (grazie, serva ${ }^{50}$ ). If the naivety and inventiveness of Norina's character are exposed in piano, the joy of Malatesta manifests itself in crescendo, realizing that the girl's acting talent will ensure victory. E.g. 24 (G. Donizetti - Don Pasquale, Edizione Ricordi, Milano, 2006, Act I, Recitativo e Duetto Finale I: Pronta io son, p. 57, ms. 103-104):

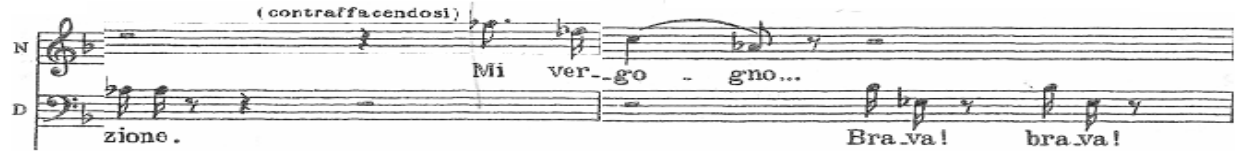

After the final touches meant to make Sofronia's interpretation absolutely perfect (collo torto, torto ${ }^{51}$, bocca stretta, stretta $^{52}$ ), the doctor's full satisfaction

\footnotetext{
${ }^{45}$ You want me to be proud (t.a.Cr.S.A.).

${ }^{46}$ Or be sad (t.a.Cr.S.A).

${ }^{47}$ You want me to cry (t.a.Cr.S.A).

${ }^{48}$ Or scream (t.a.Cr.S.A).

${ }^{49}$ A simple, humblegirl (t.a.Cr.S.A).

${ }^{50}$ Thank you, I'm the servant (t.a.Cr.S.A).

${ }^{51}$ Wry neck (t.a.Cr.S.A.).
} 
is expressed by a melisma tempo on the word brava. E.g. 25 (G. Donizetti - Don Pasquale, Edizione Ricordi, Milano, 2006, Act I, Recitativo e Duetto Finale I: Pronta io son, p. 58, ms. 110-115):

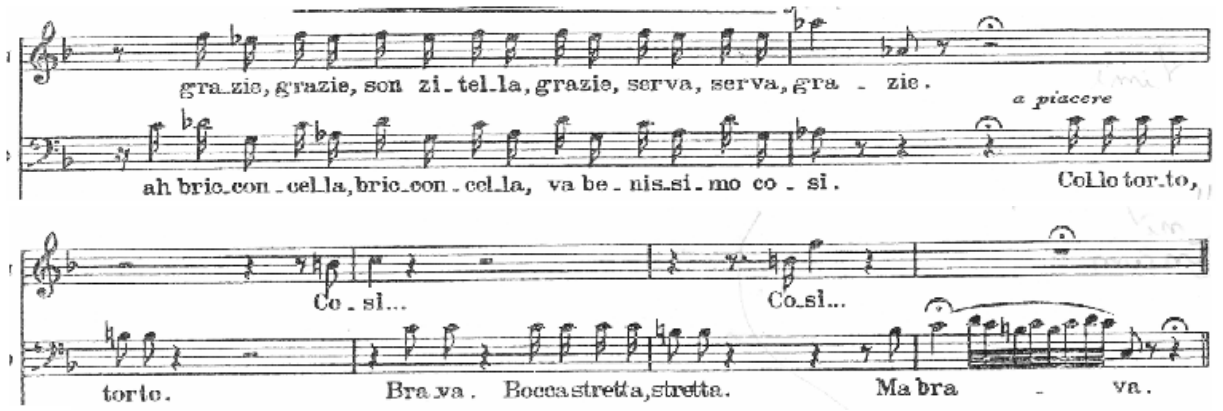

The last part of the duet develops the joy and safety of triumph in front of Don Pasquale; there are three repetitive periods: the first period (vado, corro al gran cimento, pieno ho il core d'ardimento ${ }^{53}$ ) has a gradual, ascending and descending melodic course, exceptional triolet values with a sudden passage from forte to piano and then by one crescendo (last two measures) returns to forte. The same melodic, rhythmic, dynamic and orchestral play is taken over by Malatesta (different text), showing the common goal. The second period starts with a rhythmic-melodic material based on a punctuated value cell and a short value of melodically broken course, in piano, expressing the desire to trifle with Don Pasquale. The orchestration is quite simple, with (bass) accompaniment of equal eighths followed by eighths pauses, and the melodic line in the upper plane doubles the voices. E.g. 26 (G. Donizetti - Don Pasquale, Edizione Ricordi, Milano, 2006, Act I, Recitativo e Duetto Finale I: Pronta io son, p. 60, ms. 129-135):

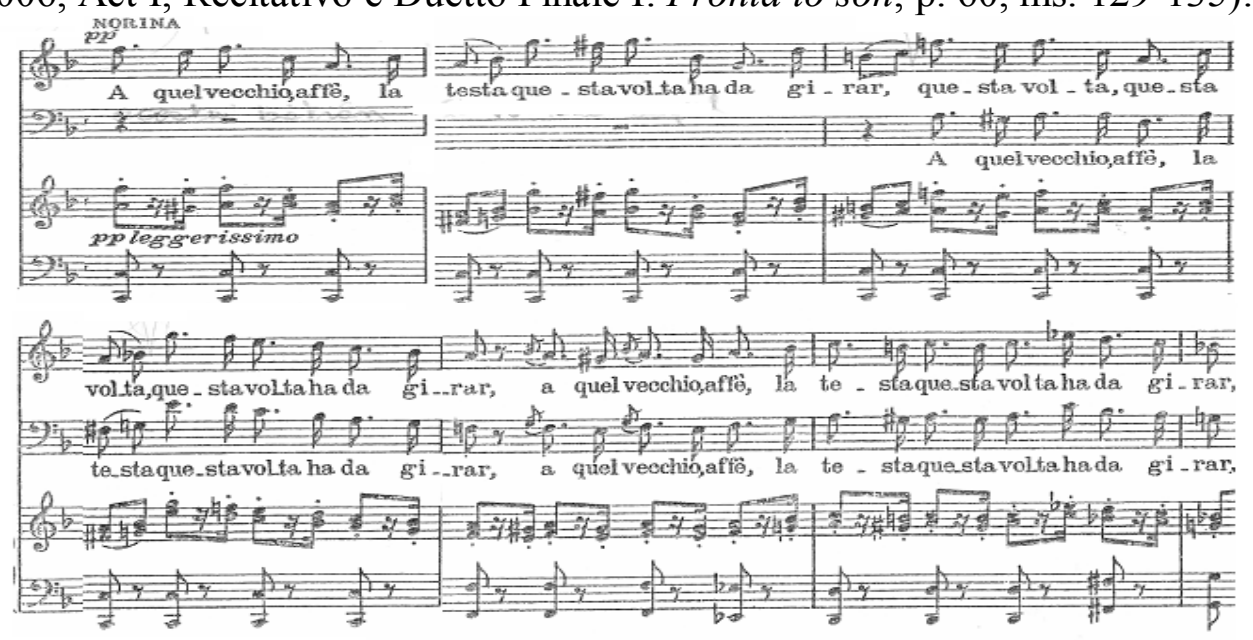

The third period arises some musical issues generated by the occurrence of ascending chromatisms. After a short recitative fragment (the impatience to implement the plan), the musical motif (the enthusiasm they feel when starting to fight against Don Pasquale) is completely resumed and, at the end of the duet (Pochissimo ritenuto) a recapitulation of the scenario full of irony and mockery prepared for the old man and the hope of the final victory is made (si la sapro, la

\footnotetext{
${ }^{52}$ Small, close mouth(t.a.Cr.S.A).

${ }^{53}$ I run to this great confrontation, my heart is full of passion(tr t.a.Cr.S.A.).
} 
vo' spuntar $^{54}$ ). The orchestra performs the harmonic support and concludes in the same humorous palette the farce prepared for Don Pasquale. E.g. 27 (G. Donizetti - Don Pasquale, Edizione Ricordi, Milano, 2006, Act I, Recitativo e Duetto Finale I: Pronta io son, p. 66, ms. 205-209):

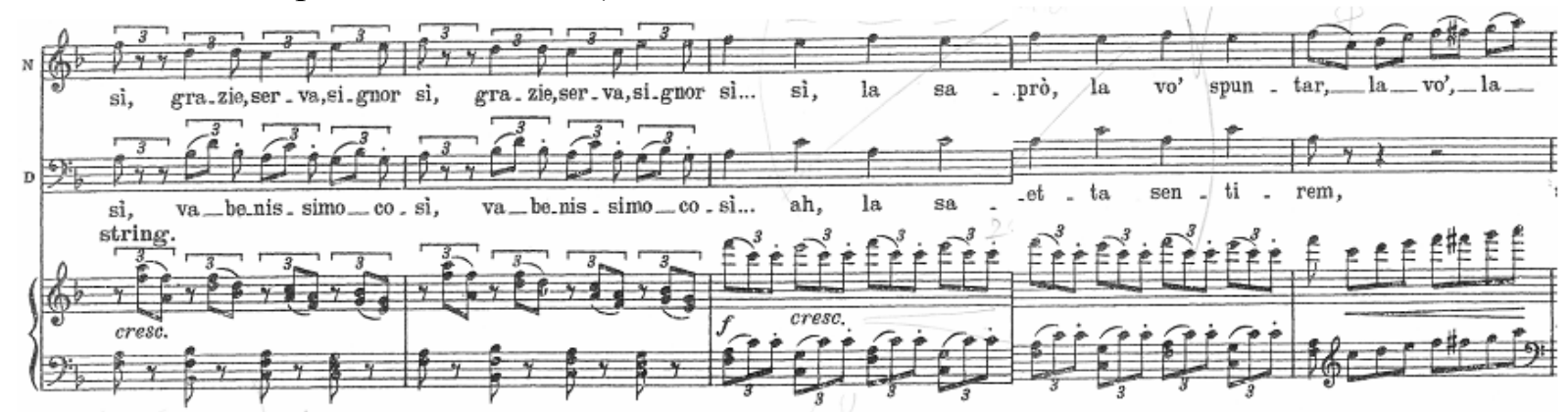

The triplet of the second act - Via, da brava: is the most difficult moment of the opera (from a theatrical perspective) for interpreter of the feminine role, forced to make very rapid changes of character, expressiveness, mimics and vocality. The asides and dialogues harmoniously blend with the help of the melodic lines built differently (the asides are played and the dialogues have the form of a recital), of tones and orchestral accompaniment. E.g. 28 (G. Donizetti - Don Pasquale, Edizione Ricordi, Milan, 2006, Act II, Scene III, Scene e Terzetto: Via, da brava, p. 78, ms. 4-8):

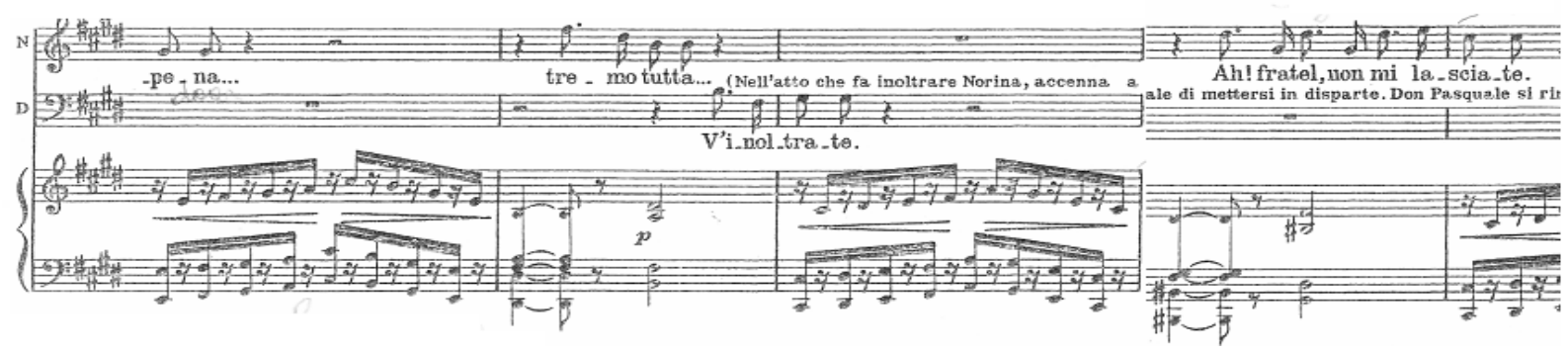

Don Pasquale is very confident that the religious education received by Sofronia at the monastery can offer him an obedient wife. On the melodic line of the girl's aside, Malatesta makes a description of which the old man understands that her attitude and expression prove simplicity and obedience, while the orchestra is singing a capricious melody that reveals Norina's true intentions: sta $a$ vedere o vecchio matto, ch'or ti servo come va ${ }^{55}$. E.g. 29 (G. Donizetti - Don Pasquale, Edizione Ricordi, Milan, 2006, Act II, Scene III, Scene e Terzetto: Via, da brava, p. 80, ms. 19-20):

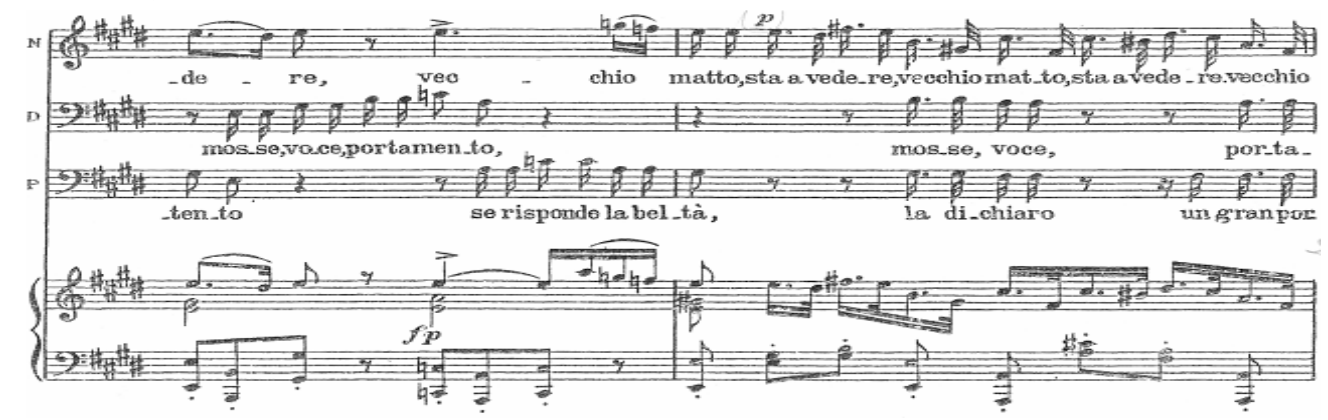

\footnotetext{
${ }^{54}$ Yeah, I'll know how to defeat him (t.a.Cr.S.A.)

${ }^{55}$ You'll see, crazy old man, I'll serve you the way you deserve (t.a.Cr.S.A.).
} 
Sofronia's melodic line in asides is broken, and the sinuous course (quarter and sixteenth notes) combines the staccato and legato notes. The change of tempo (Più allegro) and the indication con terrore ${ }^{56}$ describe a Sofronia "horrified" by the presence of another man except her brother (short rhythmicmelodic cells that find their answer in the orchestration cells), and agitatissima translates an exaggerated emotional disorder, asking the "brother", in her hypocrisy, to leave the house immediately. E.g. 30 (G. Donizetti - Don Pasquale, Edizione Ricordi, Milano, 2006, Act II, Scene III, Scena e Terzetto: Via, da brava, p. 81-82, ms. 33-37):

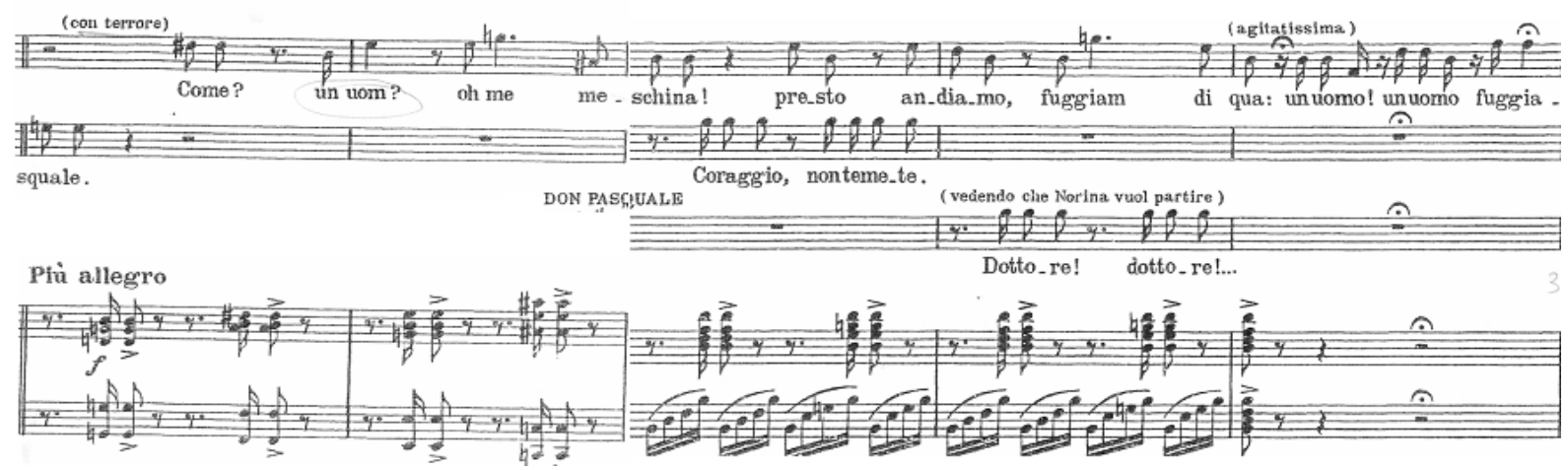

Pasquale's happiness knows no boundaries believing that the ideal wife is in front of his eyes (com'e cara, com'e cara! ${ }^{57}$ ). In a brief exchange of correspondence between Malatesta and Norina, the girl gets assured that the script and the interpretation have already convinced the old man. The dynamics remains in a low register due to the Norina - Malatesta and Malatesta - Don Pasquale asides, and the orchestra doubles the solist line and realizes the harmonic support. E.g. 31 (G. Donizetti - Don Pasquale, Edizione Ricordi, Milan, 2006, Act II, Scene III, Scene e Terzetto: Via, da brava, p. 82, ms. 38-41):

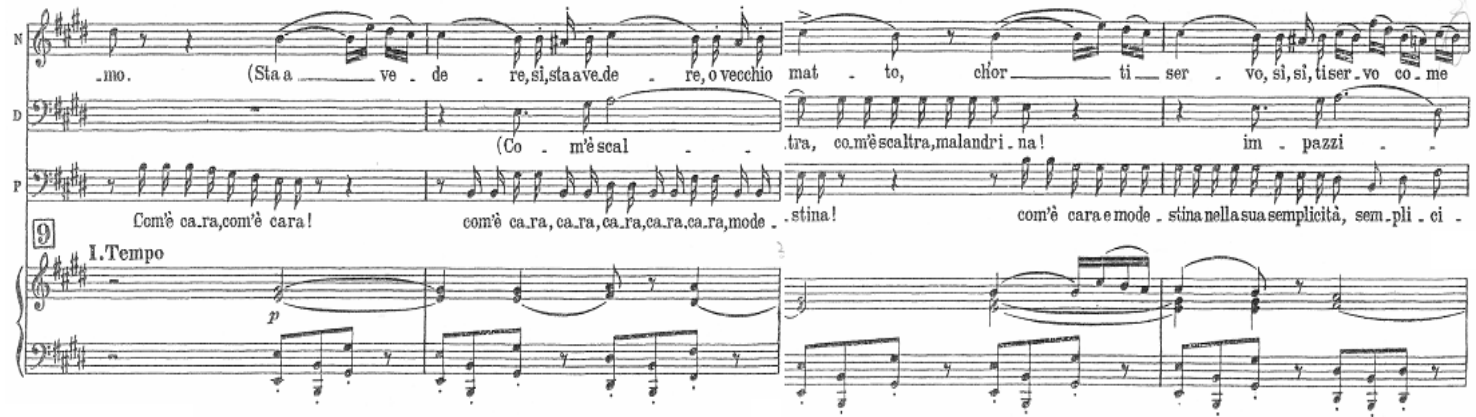

With the signing of the marriage contract we find the unexpected gesture of the old man: he gives his wife half of the entire fortune, causing a wave of words of gratitude: rivela il vostro core quest'atto di bonta ${ }^{58}$. The unexpected appearance of Ernesto (who has no knowledge of Malatesta's script) can ruin all their plans, and the change of tempo to Allegro, the orchestration (tremolo) and the piano tone describe the panic created. E.g. 32 (G. Donizetti - Don Pasquale, Edizione Ricordi, Milano, 2006, Act II, Quartetto Finale II: indietro, p. 96, ms. 143-151):

\footnotetext{
${ }^{56}$ With horror(t.a.Cr.S.A.).

${ }^{57}$ What a cute, cute girl! (t.a.Cr.S.A.).

${ }^{58}$ This gesture shows how noble you are (t.a.Cr.S.A.).
} 


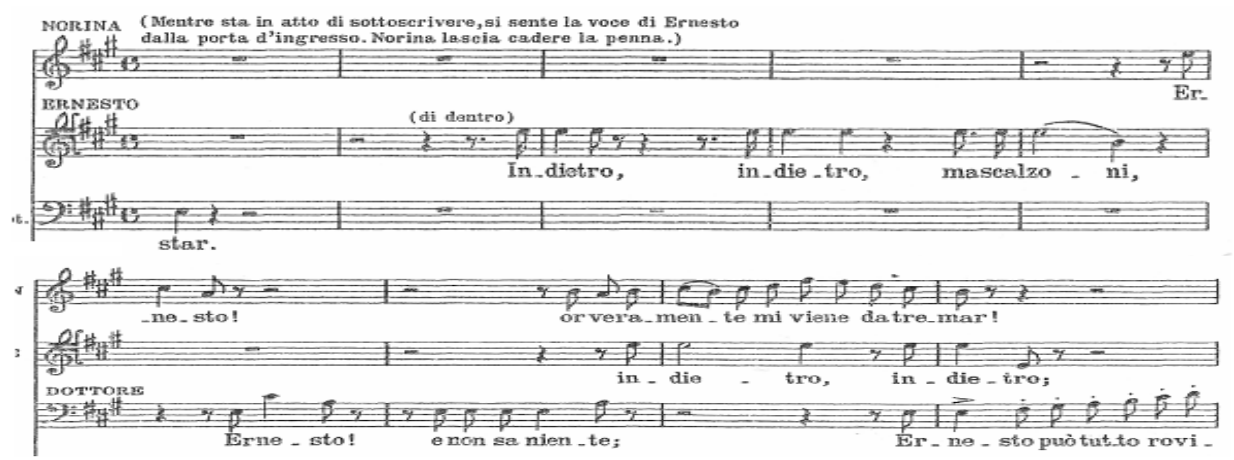

The fifth scene - Pria di partir (senza badare agli altri, va diritto a Don Pasquale $^{59}$ ) Ernesto comes to say farewell to the old man, but the latter (in ecstasy) asks him to witness his marriage. Ernesto remains stunned when he recognizes his own lover in the elder's future wife, but Malatesta hastily whispers that it is a farce, while Norina honestly states this time: adesso veramente, mi viene da tremare" ${ }^{60}$. E.g. 33 (G. Donizetti - Don Pasquale, Edizione Ricordi, Milano, 2006, Act II, Quartetto Finale II, Scene V: Pria di partir, p. 98, ms. 197199):

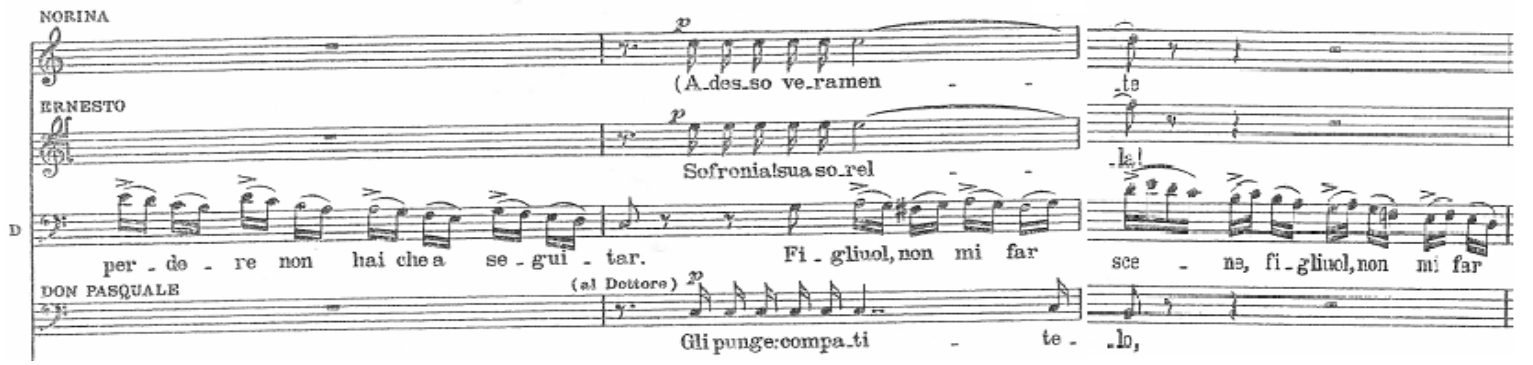

Ernesto understands and immediately becomes part of the game signing as a witness to the marriage between Pasquale and Sofronia. Moderato mosso (6/8) prepares a crucial moment for the opera's action: Pasquale approaches his wife to embrace her, but she refuses it because he did not ask her permission first. Although the indication respingendolo con dolcezza ${ }^{61}$ tends to suggest that Norina would give ground, the orchestral accompaniment (quaversstaccato) and the bass line (ostinato) reveals her hidden thoughts. Pasquale contrariately obeys and asks for her acceptance, but this time the short answer: no makes Ernesto burst into laughter. E.g. 34 (G. Donizetti - Don Pasquale, Edizione Ricordi, Milano, 2006, Act II, Quartetto Finale II, Scene V: Pria di partir, p. 104, ms. 242-250):

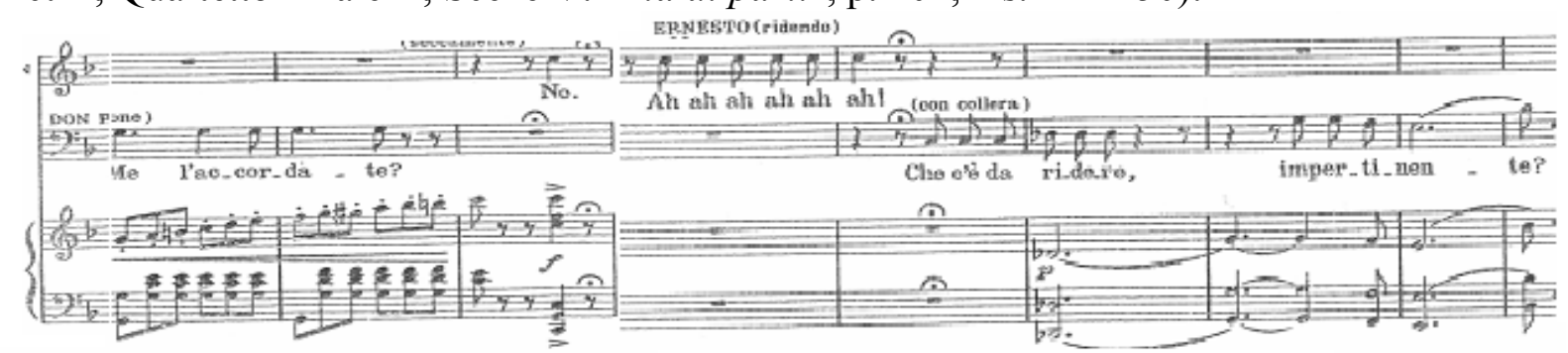

\footnotetext{
${ }^{59}$ Without noticing anyone, she goes straight to Don Pasquale (t.a.Cr.S.A.).

${ }^{60}$ Now I'm really shaking (t.a.Cr.S.A.).

${ }^{61}$ Rejecting him gently (t.a.Cr.S.A.).
} 
This rudeness provokes the old man's wrath, who banishes his nephew, but Sofronia's angry and contemptuous intervention interrupts him with a forte exclamation (prepared by three orchestral chords), and the girl suddenly turns into another person, shocking Pasquale. She does give too much time to the old man to recover but resumes the attack and asks Ernesto to stay in the house to become her knight. The accents on the words decrepito ${ }^{62}$ (Pasquale) and giovane $^{63}$ (Ernesto) are meant to highlight the different ways that Sofronia addresses the two men. E.g. 35 (G. Donizetti - Don Pasquale, Edizione Ricordi, Milano, 2006, Act II, Quartetto Finale II, Scene V: Pria di partir, p. 106, ms. 288-291):

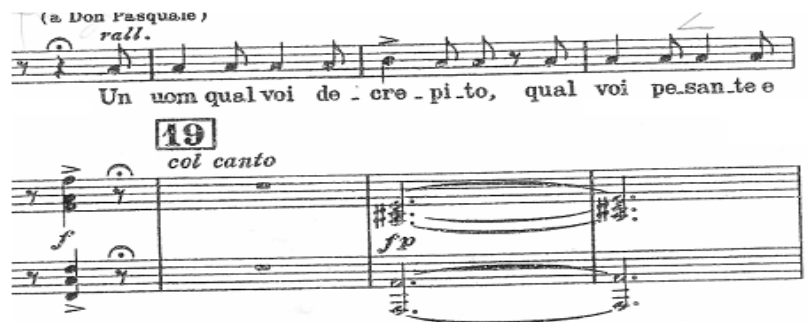

The replies between spouses have the following indications: freddamente ${ }^{64}$, risoluto $^{65}$, con ischerno ${ }^{66}$, and the short orchestra chords and the forte tone describe the fuss produced. A fermata on a break is meant to calm Sofronia, very close to strike Pasquale because of the tension created. Donizetti was not only a great musician, he also thought of the scenic solving of his operas. Thus, on the indication facendosi presso a Don Pasquale, con dolcezza affettata ${ }^{67}$ Sofronia runs a tempo that prepares the true transformation and from this moment, regardless of whether or not the character's name remains Sofronia, the behavior belongs to Norina. The apparent gentleness of the reply idolo mio, vi supplico scordar questa password ${ }^{68}$ extinguishes in a cry (parola), then, in an alert tempo, in forte, with accents (tutti obbedir ${ }^{69}$ ) Norina asks everyone to execute her orders, including Don Pasquale. Malatesta's aside and the old man's attempts to resist do not have the power to go over the girl's fierce entrances. E.g. 36 (G. Donizetti - Don Pasquale, Edizione Ricordi, Milano, 2006, Act II, Quartetto Finale II, Scene V: Pria di partir, p. 108, ms. 324-336):

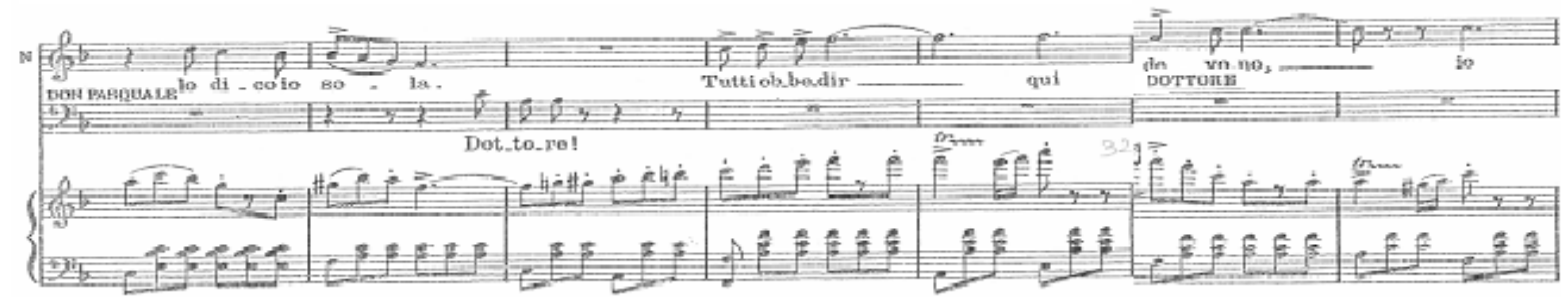

\footnotetext{
${ }^{62}$ Decrepit (It.).

${ }^{63}$ Young(It.).

${ }^{64}$ Very cold (It.).

${ }^{65}$ With determination (It.).

${ }^{66}$ With scoff (t.a.Cr.S.A.).

${ }^{67}$ Approaching Don Pasquale with pretended goodness(t.a.Cr.S.A.).

${ }^{68} \mathrm{My}$ idol, please, forget that word (t.a.Cr.S.A.).

${ }^{69}$ Everybody listens (t.a.Cr.S.A.).
} 


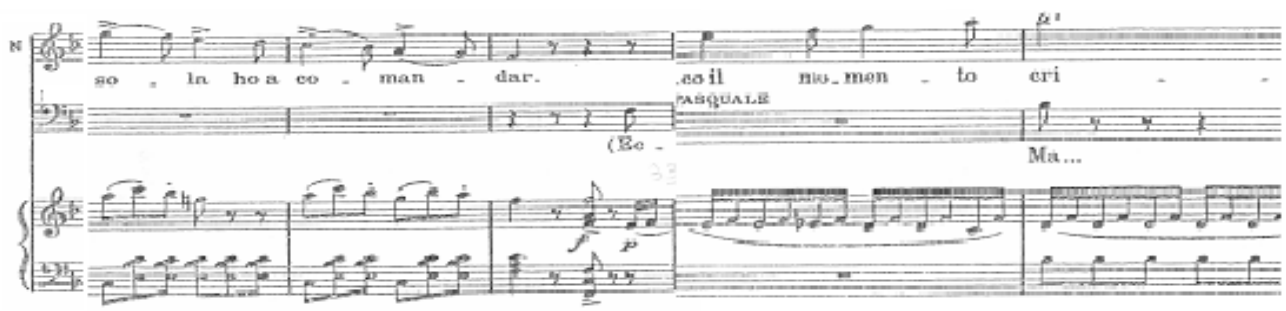

The scene's climax is reached on the reply taci (si2) prolonged over orchestral accompaniment (fortissimo) through a short recitative (con minaccia a Don Pasquale ${ }^{70}$ ) Norina then explains how things will stay in the house she now masters. The effect of the girl's cries is immediately seen after the corona on break, when Pasquale remains frozen (like Don Bartolo in The Barber of Seville by Rossini), unable to understand anything of what is happening, only managing to mumble: Sogno? Veglio? Cos'e stato? Calci? Schiaffi ${ }^{71}$. Ernesto and Norina make fun of the puzzled old man: non ha sangue nelle vene ${ }^{72}$. E.g. 37 (G. Donizetti - Don Pasquale, Edizione Ricordi, Milano, 2006, Act II, Quartetto Finale II, Scena V: Pria di partir, p. 111-112, ms. 360-368):

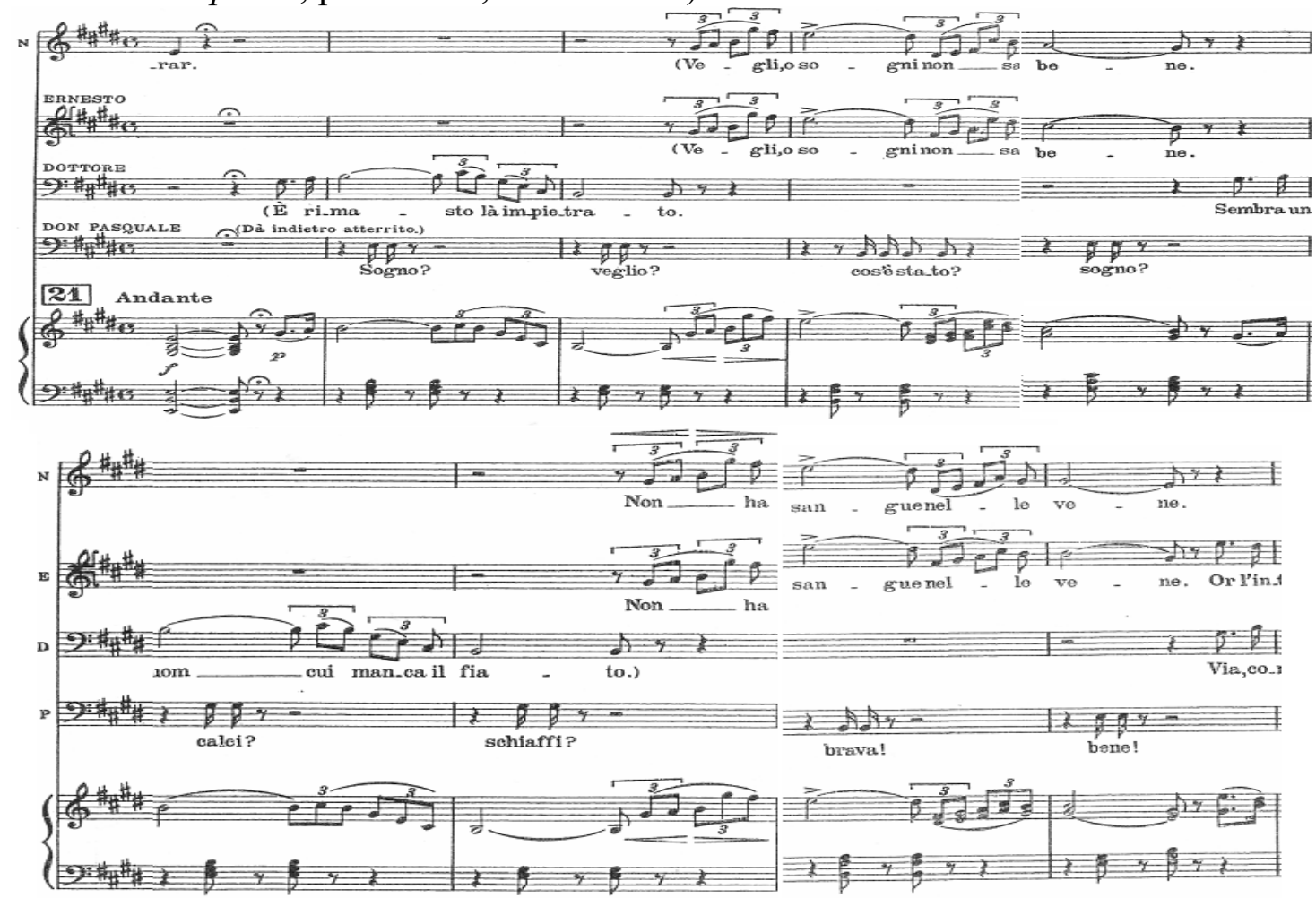

With Pasquale's replies (e donna a farma tremar ${ }^{73}$ ), Ernesto (comincio a decifrar ${ }^{74}$ ) and Malatesta (a sgomentar ${ }^{75}$ ), Norina performs a vocal note starting from note La2 (descending course to Rel) expressing the satisfaction that Pasquale was defeated. E.g. 38 (G. Donizetti - Don Pasquale, Edizione Ricordi, Milano, 2006, Act II, Quartetto Finale II, Scene V: Pria di partir, p. 116, ms. 393-394):

\footnotetext{
${ }^{70}$ Minaciously to Don Pasquale (t.a.Cr.S.A.).

${ }^{71}$ Am I dreaming? Am I awake? What is this? Hitting? Slapping? (t.a.Cr.S.A.).

${ }^{72}$ He has no more blood in his veins (t.a.Cr.S.A.).

${ }^{73}$ This woman makes me tremble (t.a.Cr.S.A.).

${ }^{74}$ I'm beginning to understand (t.a.Cr.S.A.).

${ }^{75}$ Frightened (It.).
} 


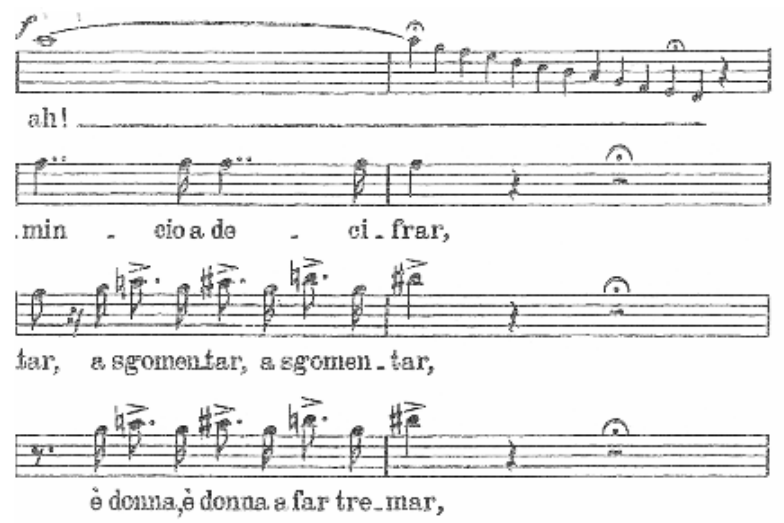

Sofronia (forte) portrays the sovereign authority of the house and gathers all servants to give them the new instructions, then asks Pasquale: di servitu novella pensate a provvedermi; sia gente fresca e bella, tale da farci onor. Di legni un paio sia domani in scuderia; quant'ai cavalli poi, lascio la scelta a voi ${ }^{76}$. E.g. 39 (G. Donizetti - Don Pasquale, Edizione Ricordi, Milano, 2006, Act II, Quartetto Finale II, Scene V: Pria di partir, p. 119, ms. 428-436):
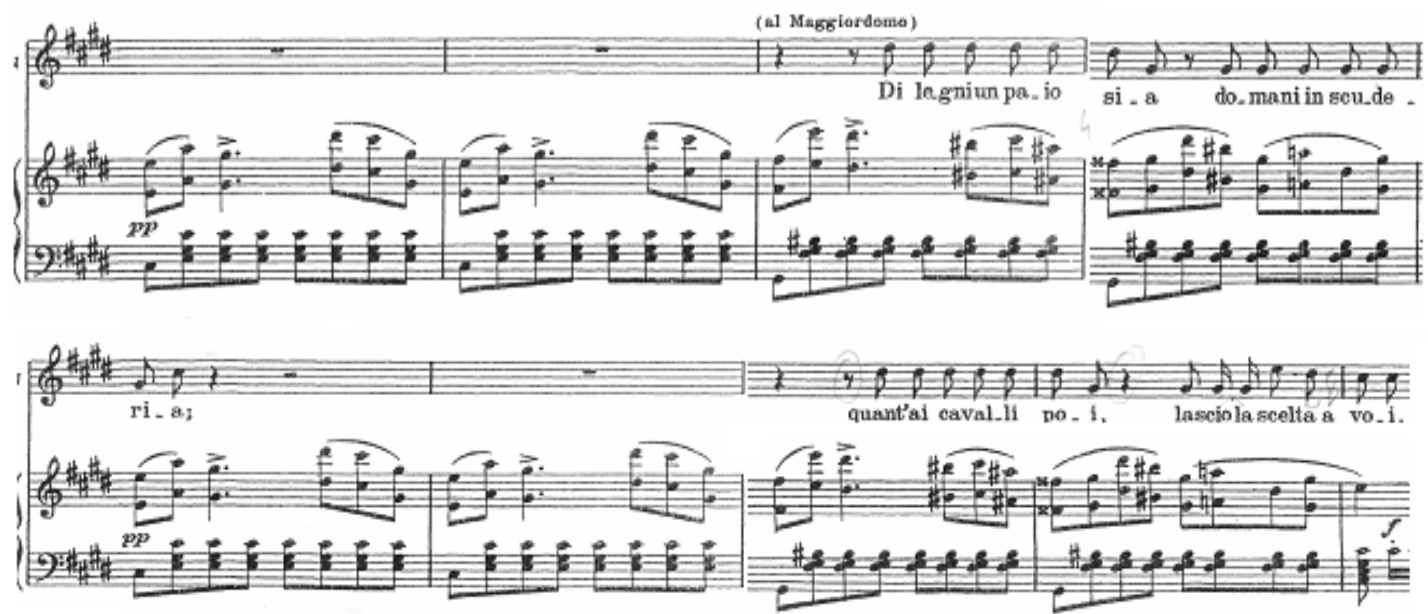

Without being intimidated by the old man's comments, Sofronia stubbornly persists in her ideas (cadential phrases - fate le cose in regola ${ }^{77}$ and not facciam burlar $^{78}$ ). E.g. 40 (G. Donizetti - Don Pasquale, Edizione Ricordi, Milano, 2006, Act II, Quartetto Finale II, Scene V: Pria di partir, p. 121, ms. 450-454):

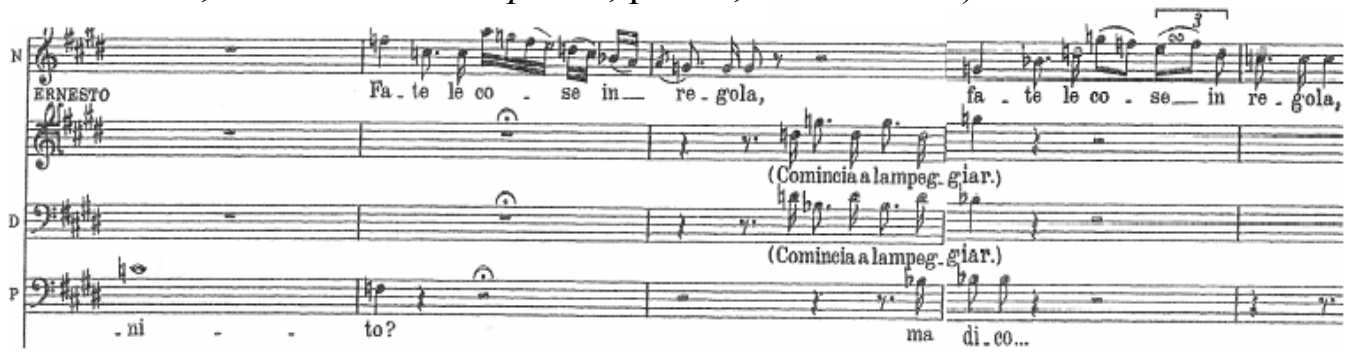

Sofronia addresses the old man a series of insults (con furia crescendo, accelerando poco a poco, to forte) which give rise to a quartet, in which each character expresses his thoughts about the newly created situation. E.g. 41 (G.

\footnotetext{
${ }^{76}$ Think of bringing me new servants; I want young and beautiful people to honor us. I want to find a bunch of wood tomorrow in the stable; as about the horses, the choice is yours (t.a.Cr.S.A.).

${ }^{77}$ Let's do things right(t.a.Cr.S.A.).

${ }^{78}$ Do not joke about it (t.a.Cr.S.A.).
} 
Donizetti - Don Pasquale, Edizione Ricordi, Milano, 2006, Act II, Quartetto Finale II, Scene V: Pria di partir, p. 123, ms. 470-473):

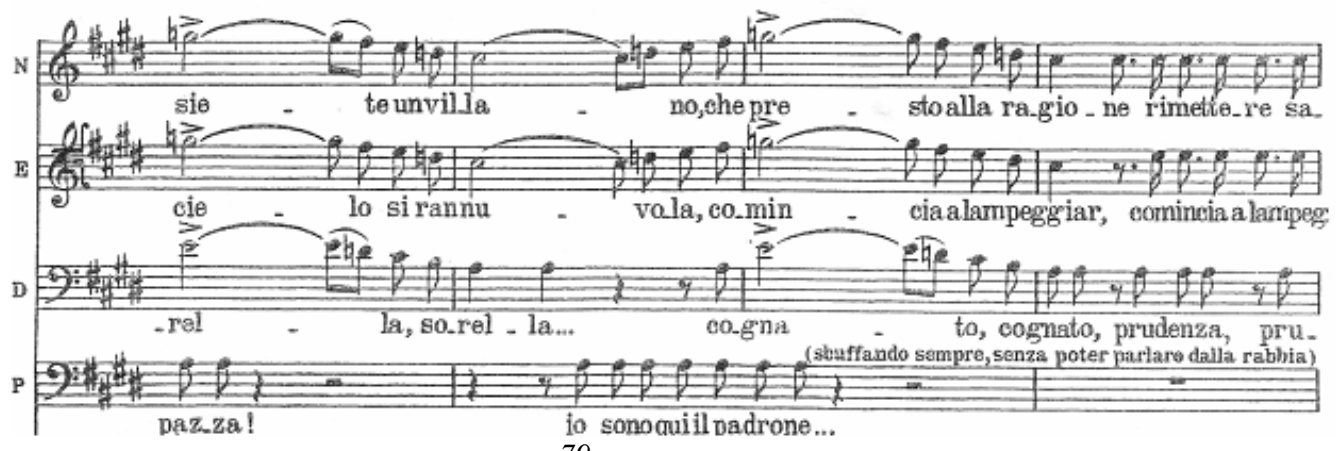

After calling Pasquale villano ${ }^{79}$, everything turns into infernal turmoil. Two coronas on the lines Io?, io? prepare the end and the old man expresses his revolt in vivace (melodically broken course, close to the spoken language), considering that he was betrayed and his life turned into a real slog. The orchestral accompaniment doubles and melodically completes the sustained solo parts and a wide dynamic with sudden passes from forte to piano (on one measure). Crescendo, piano and forte follows the requirements of stage expressiveness and the indication Più presto, into the fortissimo amplifies the climax of this ensemble.

The Norina - Don Pasquale duet: Signorina, in tanto fretta: is placed in the third act, after Pasquale's recitative monologue, in which he mourns his fate and seeks solutions to escape the tyranny of his wife. The scene is described as follows: Norina entra correndo e, senza badare a Don Pasquale, fa per uscire. $E$ vestita in grandissima gala, ventaglio in mano ${ }^{80}$. The old man is very curious to know where his wife leaves in tantra fretta? ${ }^{81}$ (a melodic line that fits the literary text with great fidelity). If punctuated notes values suggest Pasquale's extreme irritation, Sofronia illustrates the ironic and contemptuous manner in which the old man is treated. The accompaniment of short or small sixteenth cells illustrate Pasquale's inner turmoil and home atmosphere, and the nuances highlight the tension in the two spouses' dialogues. Every phrase begins in piano and suddenly ends with an agreement in forte, then immediately returns to piano. E.g. 42 (G. Donizetti - Don Pasquale, Edizione Ricordi, Milano, 2006, Act III, Scene II, Duetto: Signorina, in tanto fretta, p. 143, ms. 4-18):

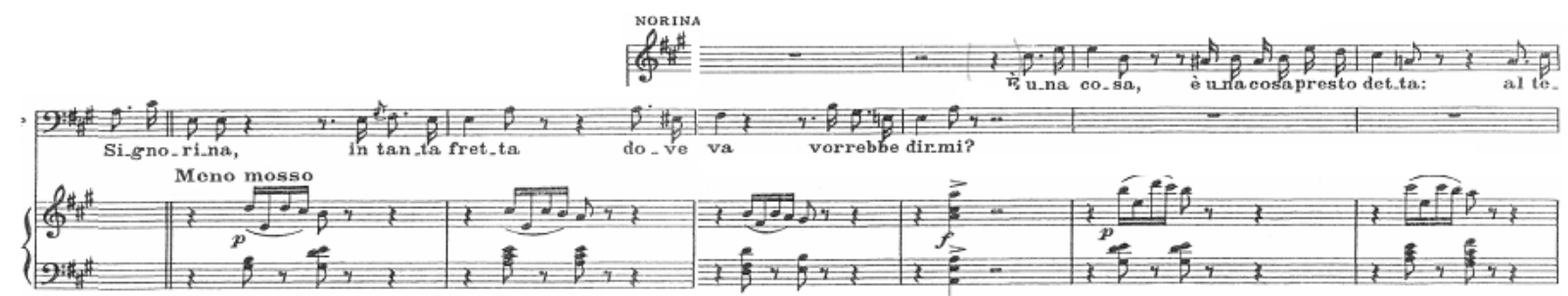

\footnotetext{
${ }^{79}$ You savage peasant(It.).

${ }^{80}$ Norina comes running, and without paying attention to Don Pasquale, she heads to the exit. She's dressed up, with a fan in her hand (t.a.Cr.S.A.).

${ }^{81}$ She's in such hurry(t.a.Cr.S.A.).
} 


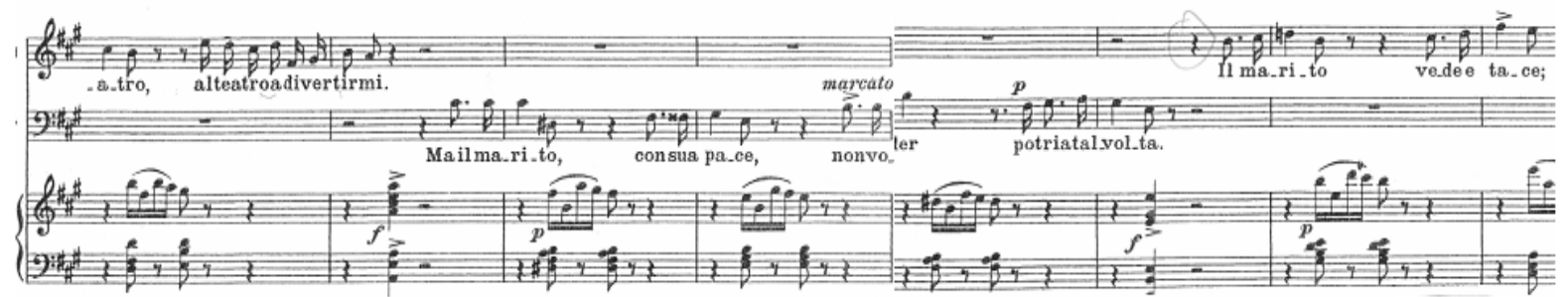

Pasquale's attempt to prevent his wife from going to theater causes a scandal that is gradually amplifying (musical cells placed towards the forte acute register, with small note values and sixteenth notes accompaniments over which another sound plane appears - accents in first and third tempos). The insolent observation: il marito quando parla non s'ascolta ${ }^{82}$ infuriates poor Pasquale, who answers by apostroping her in forte, più allegro, on a broken melodic course, relatively low ambitus, with the continuous repetition of the quaver values, accompanied by sixteenth notes and small crescendos - diminuendo. Vada a letto, dorma bene, poi doman si parlera ${ }^{83}$ sung con aria di motteggio ${ }^{84}$ clearly shows Sofronia's disregard toward the weak character, his access of rage being just another reason for mockery (sounds staccato, melisma and descendant roulades, and the orchestra plays short chords like bursts of laughter). This reply resumes in rallentando, sarcastically imitating a lullaby. The climax of the scandal is the moment when Sofronia gli da uno schiaffo ${ }^{85}$ and we come to know a humiliated Pasquale who wants to die, and a Norina with remorse, proving that her soul background is still good. E.g. 43 (G. Donizetti Don Pasquale, Edizione Ricordi, Milano, 2006, Act III, Scene II, Duetto: Signorina, in tanto fretta, p. 146, ms. 58-64):

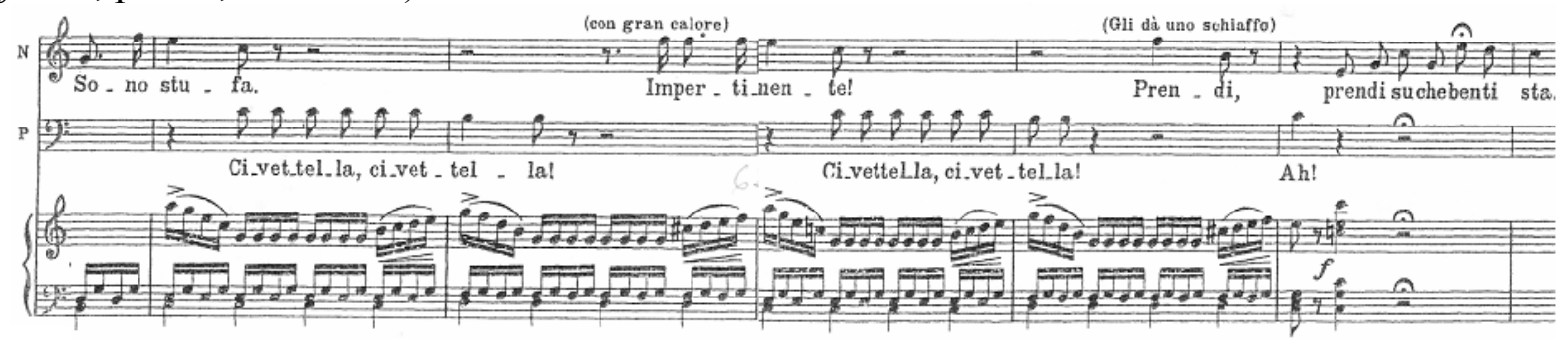

The fermata of the orchestra and the note $m i$ of the voice, depicts the old man's stupefaction who had never believed that the girl would complete the threat of the quartet Provato ho a prenderti finora colle buone, Saprò se tu mi stuzzichi, le mani adoperar ${ }^{86}$ ). His suffering and Norina's remorse bring changes of tempo (Larghetto, 6/8), and the melodic line is transferred to the orchestra, imitating the tears spilled by the old man (two short musical motifs followed by a cell made of a descending quinte). The combination between the dotted rhythm and the crescendo is the expression of deep grief and soreness that causes Pasquale to conclude: altro a fare non ti resta, che d'andarti ad

\footnotetext{
${ }^{82}$ When the husband speaks she does not listen (t.a.Cr.S.A.).

${ }^{83}$ Go to bed, sleep well, and tomorrow we'll talk(t.a.Cr.S.A.).

${ }^{84}$ Mocking him (t.a.Cr.S.A.).

${ }^{85}$ She slaps him (t.a.Cr.S.A.).

${ }^{86}$ So far I've been trying to ride you in the snaffle, but if you keep provoking me, I'll use my hands (t.a.Cr.S.A.).
} 
affogar $^{87}$. Although she feels remorse, Norina is also aware that only this way her victory is assured (a melodic line with a descending contour, doubled by violins, flute and oboe, on a varied dynamic palette, with sudden passes from forte to piano or small crescendo - diminuendo). From the overlapping of the two voices we understand the contradictory states: Pasquale's shock and suffering, and Norina's perseverance. E.g. 44 (G. Donizetti - Don Pasquale, Edizione Ricordi, Milano, 2006, Act III, Scene II, Duetto: Signorina, in tanto fretta, p. 149, ms. 112121):

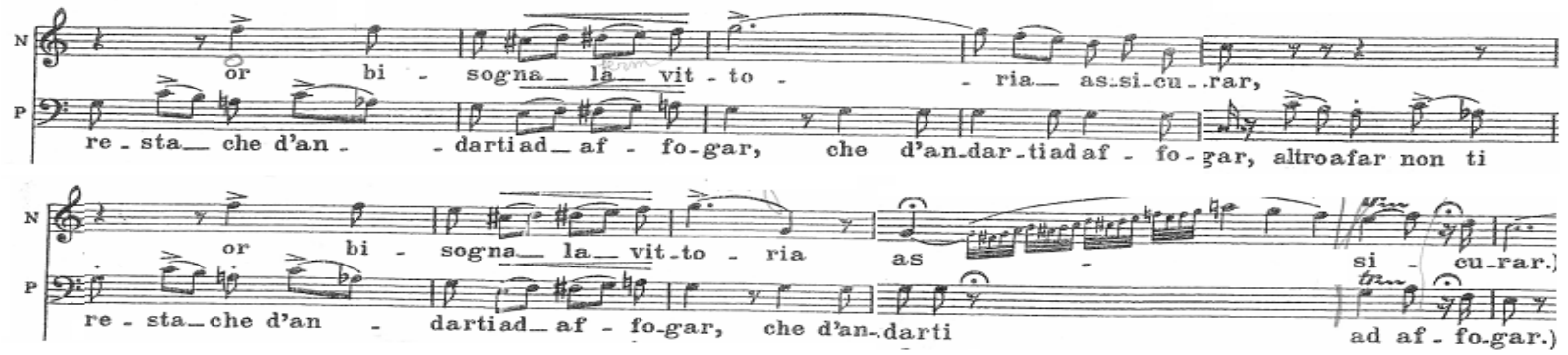

After a short free tempo,(D Major) Norina decides to take her role to the end, forgetting the moment of weakness. From the previous Larghetto we pass through poco più to a new Allegro (the accumulation of the scene tension and the anger of Don Pasquale triggered by the reply parto a dunque ${ }^{88}$ ). The girl's insolence manifests on a capricious melodic line of punctuated rhythm and short motifs ( $c i$ vedremo al nuovo giorno ${ }^{89}$ ) that show that the game continues. Pasquale keeps repeating: porta chiusa trovera ${ }^{90}$, which infuriates Norina (tempo on sposo with two fermata), the dialogue being conducted in forte, with an accompaniment with accents on measure four. E.g. 45 (G. Donizetti - Don Pasquale, Edizione Ricordi, Milano, 2006, Act III, Scene II, Duetto: Signorina, in tanto fretta, p. 150, ms. 132-134):

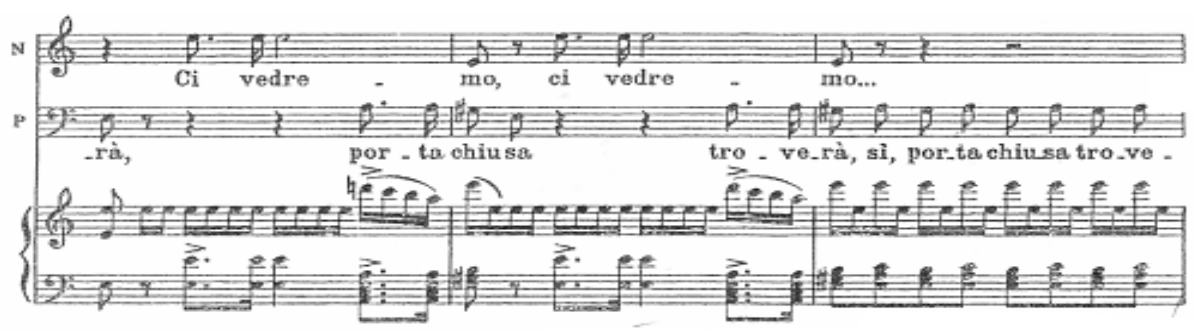

Vivace, ma non tropo, $3 / 8$, con civetteria $^{91}$ are the following indications describing a initial simple melodic line, the harmonic accompaniment in piano, with an apparently positive sense (Via, caro sposino, non farmi il tiranno, sii dolce, bonino ${ }^{92}$ ), but the following phrase shows us the insidious game of the girl: rifletti all'eta ${ }^{93}$. E.g. 46 (G. Donizetti - Don Pasquale, Edizione Ricordi, Milano, 2006, Act III, Scene II, Duetto: Signorina, in tanto fretta, p. 151, ms. 138-152):

\footnotetext{
${ }^{87}$ There's nothing else left but to go drown yourself (t.a.Cr.S.A.).

${ }^{88}$ So I'm leaving (t.a.Cr.S.A.).

${ }^{89}$ Tomorrow we'll see(t.a.Cr.S.A.).

${ }^{90}$ You'll find the door closed (t.a.Cr.S.A.).

${ }^{91}$ With coquetry (t.a.Cr.S.A.).

${ }^{92}$ Go away, my beloved man, do not play the tyrant with me, be good and sweet and think about your age (t.a.Cr.S.A)

${ }^{93}$ Think about your age (t.a.Cr.S.A).
} 


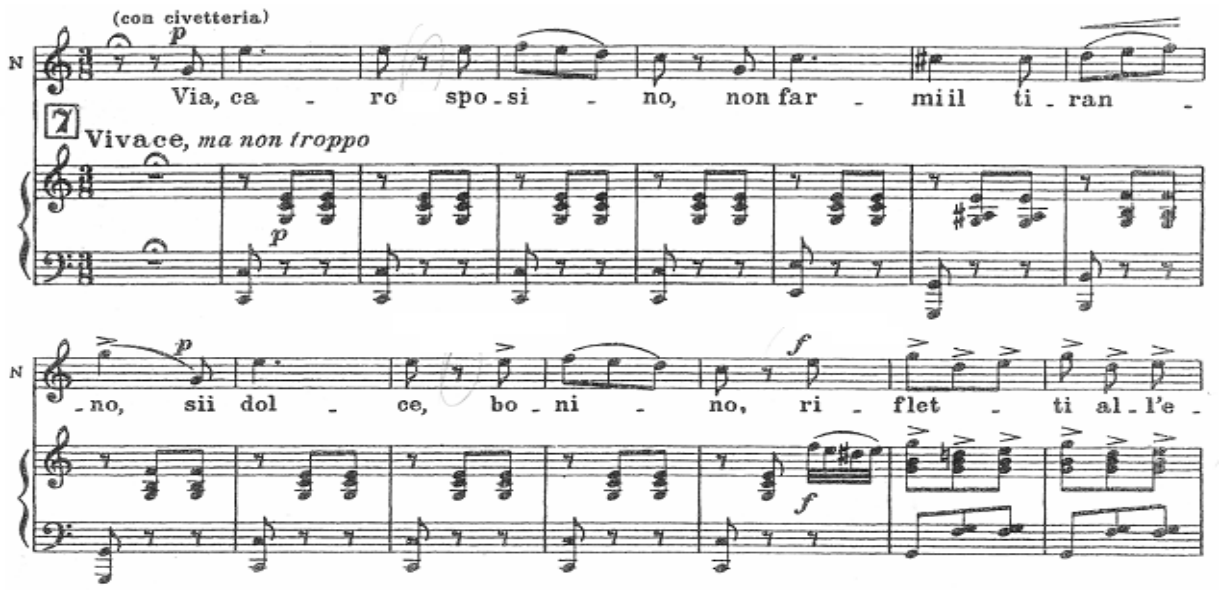

The musical phrase reveals Norina's true intentions, who continue to trifle with the poor old man (bel nonno ${ }^{94}$ ), supported by a melodic rhythm enriched with fioritura and languishing passages. E.g. 47 (G. Donizetti - Don Pasquale, Edizione Ricordi, Milano, 2006, Act III, Scena II, Duetto: Signorina, in tanta fretta, p. 151, ms. 154-166):

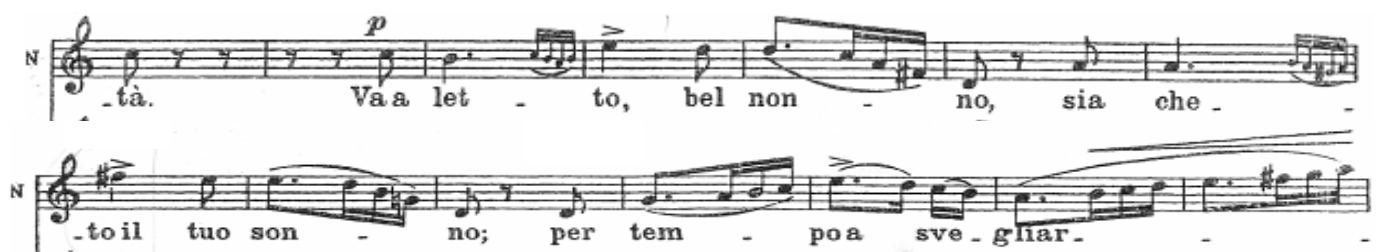

Pasquale's refusal to go to bed brings new repetitions of the previous sentences, Norina returns to the hypocrite endearment state, and her husband's response is not too long awaited, and we discover a melodic bass line by which he desperately asks: Divorzio! Che letto! Che sposa! ${ }^{95}$. The forte tone and the multitude of accents that appear almost on each sound, show the exasperation of the character despised and mocked by the one that had been so gentle and obedient at the beginning. The end of the duet belongs to the orchestra that concludes Sofronia's departure to the theater and we find a final directorial mention: Norina parte, nell'atto di partire lascia cadere una carta. Don Pasquale se ne avvede e la raccoglie $e^{96}$.

Norina - Ernesto duet: Tormani a dir che m'ami is described as follows: Norina esce con precauzione dalla parte del belvedere, e va ad aprire ad Ernesto, che si mostra dietro il cancello. Ernesto è avvolto in un mantello che lascera cadere ${ }^{97}$. The musical form of the duet is bipartite, with two periods: $\boldsymbol{A}$, $\boldsymbol{B}, \boldsymbol{A v}, \boldsymbol{B} \boldsymbol{v}$, tempo, each period being bipod.

$A$

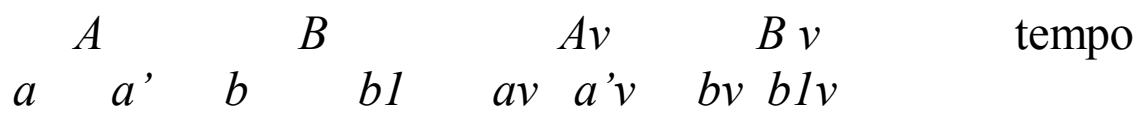

\footnotetext{
${ }^{94}$ Beautiful grandfather (t.a.Cr.S.A).

${ }^{95}$ Divorce! What a bed! What a wife! (t.a.Cr.S.A.).

${ }^{96}$ Norina leaves and before going out lets a letter fall. Don Pasquale sees it and raises it (t.a.Cr.S.A.).

${ }^{97}$ Norina prudently comes out from the garden and comes to open Ernesto, who appears behind the fence. Ernesto is wrapped in a robe that he lets fall (t.a.Cr.S.A.).
} 
The short introduction creates an atmosphere of medieval serenade, musical expression obtained by orchestration (flute, oboe and clarinet intonate the melodic line, while the strings imitate the accompaniment of guitar, pizzicato). E.g. 48 (G. Donizetti - Don Pasquale, Edizione Ricordi, Milano, 2006, Act III, Notturno: Tormani and dir che m'ami, p. 196, ms. 1-4):

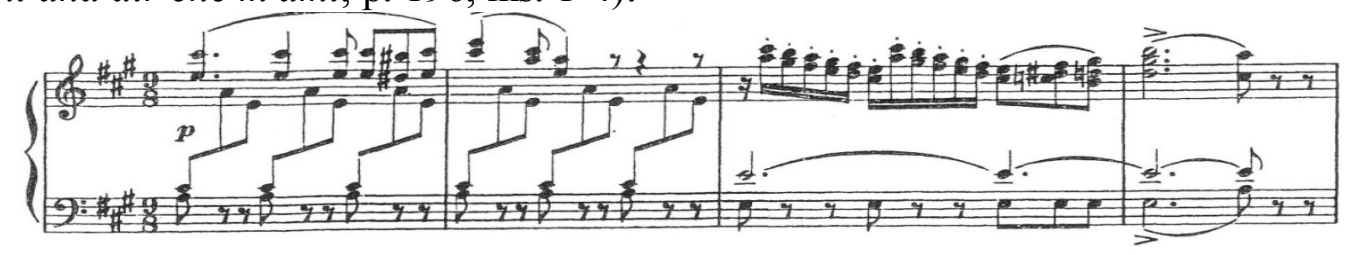

It is very interesting to note that although the soprano voice generally sings at the top of the tenor, but this time we are dealing with a roles turn-over, Norina singing to a lower third than Ernesto. This inversion was also present at the end of the second act of the opera (E rimasto la impietrato ${ }^{98}$ ), highlighting the tenor voice valences in the acute register. The duet is quite simple from the melodic point of view, with a gradual, broken course and double appoggiatura that enrich the literary sense. E.g. 49 (G. Donizetti - Don Pasquale, Edizione Ricordi, Milano, 2006, Act III, Notturno: Tormani and dir che m'ami, p. 196, ms. 5-13):

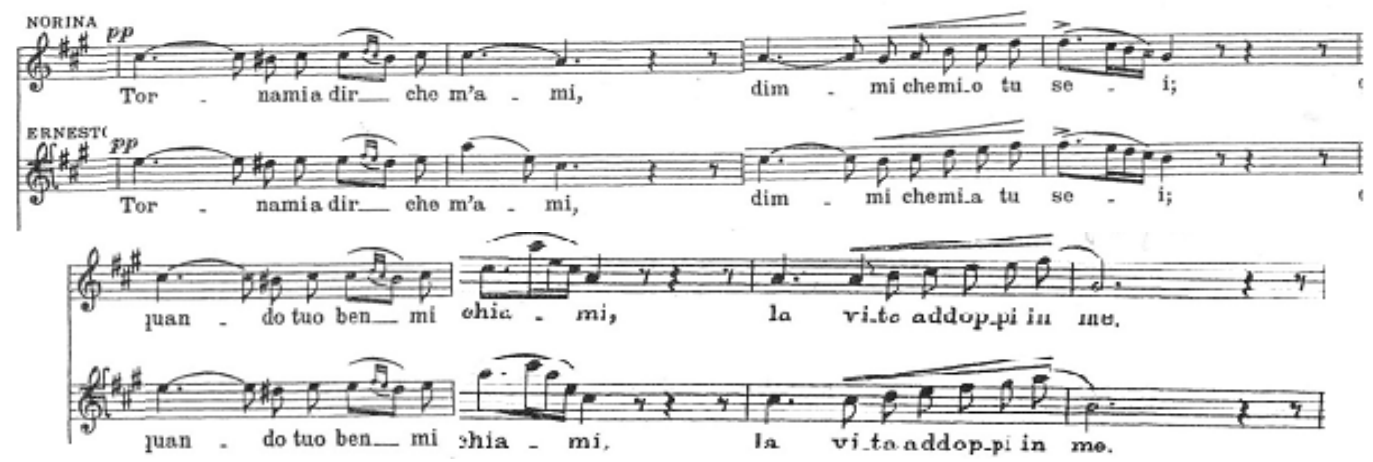

Period $\boldsymbol{B}$ is a canonical dialogue, the first motifs repeating almost identically from a melodic and rhythmic point of view, suggesting happiness and love (la voce tua si cara, rinfranca il core oppresso ${ }^{99}$ ). In the final tempo, the female voice also sings at a lower tierce unto the tenor. E.g. 50 (G. Donizetti - Don Pasquale, Edizione Ricordi, Milano, 2006, Act III, Notturno: Tormani a dir che m'ami, p. 198, ms. 25-34):

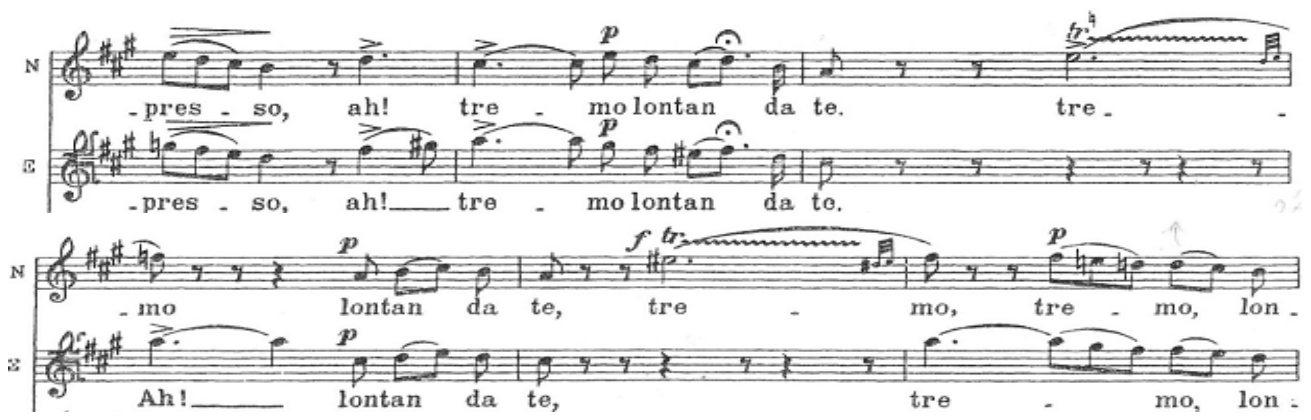

\footnotetext{
${ }^{98}$ He remained frozen (t.a.Cr.S.A.).

${ }^{99}$ Your so dear voice brings my tired heart to life (t.a.Cr.S.A.).
} 


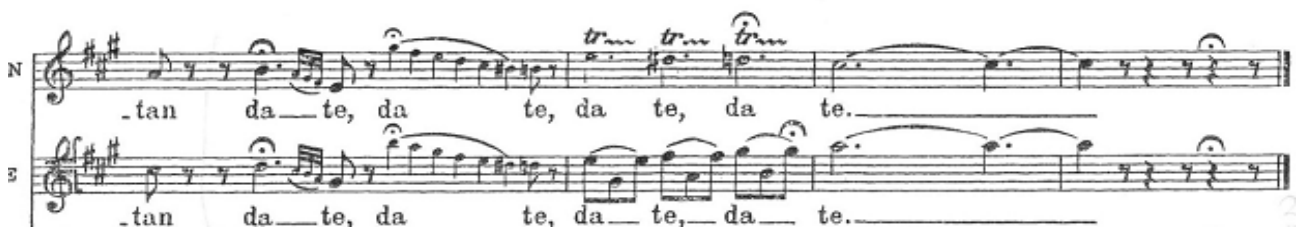

In orchestration ternary pulsation remains present almost permanently, but the vocal part is diversified according to the semantic accents; the rhythmic structure of the sentence does not change, small variations due to double appoggiatura. The piano and pianissimo tones prevail illustrating the intimacy of the moment, the gentleness and sincere love flowing from the two voices and the crescendo supports the meaning of the sentence and the text: dimmi che mio tu $\mathrm{sei}^{100}$. E.g. 51 (G. Donizetti - Don Pasquale, Edizione Ricordi, Milano, 2006, Act III, Notturno: Tormani and dir che m'ami, p. 196, ms. 7-12):
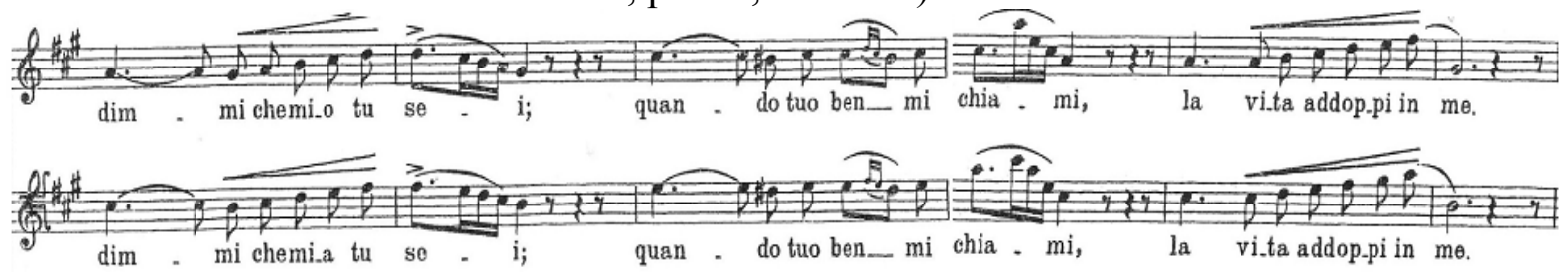

The thought of staying away from each other frightens them, being described by the immediately hidden piano tone. E.g. 52 (G. Donizetti - Don Pasquale, Edizione Ricordi, Milano, 2006, Act III, Notturno: Tormani a dir che m'ami, p. 198, ms. 24-30):

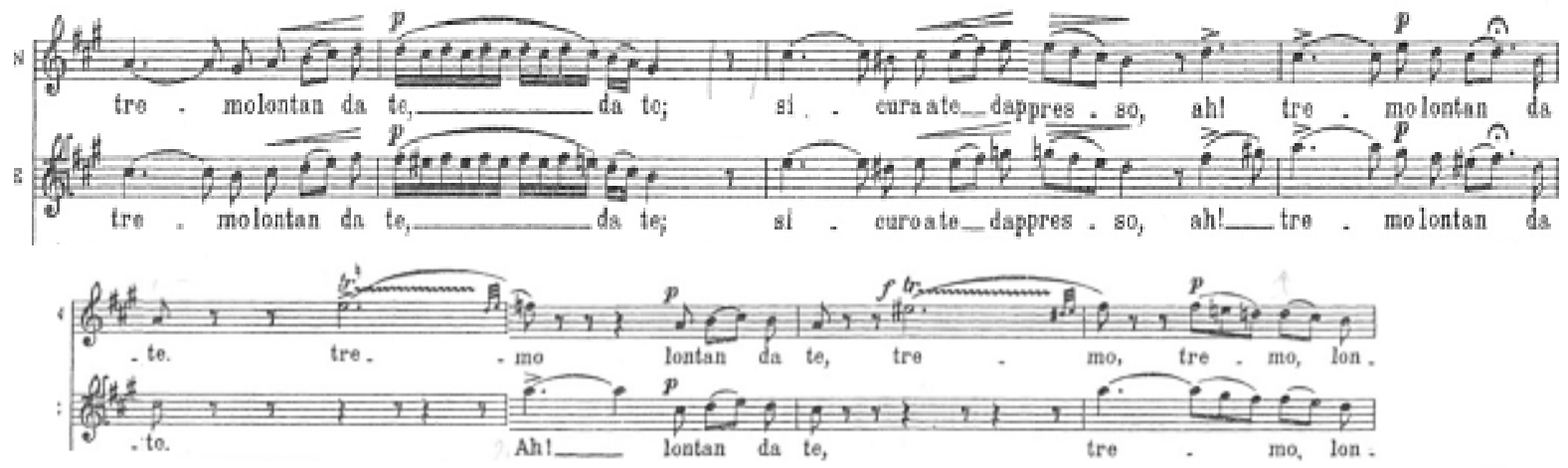

The end is like a hope-dominated confession in which the orchestra maintains its accompanying role (short interventions that lead the solist line by supporting the harmonic structure). E.g. 53 (G. Donizetti - Don Pasquale, Edizione Ricordi, Milano, 2006, Act III, Notturno: Tormani a dir che m'ami, p. 198, ms. 31-34):

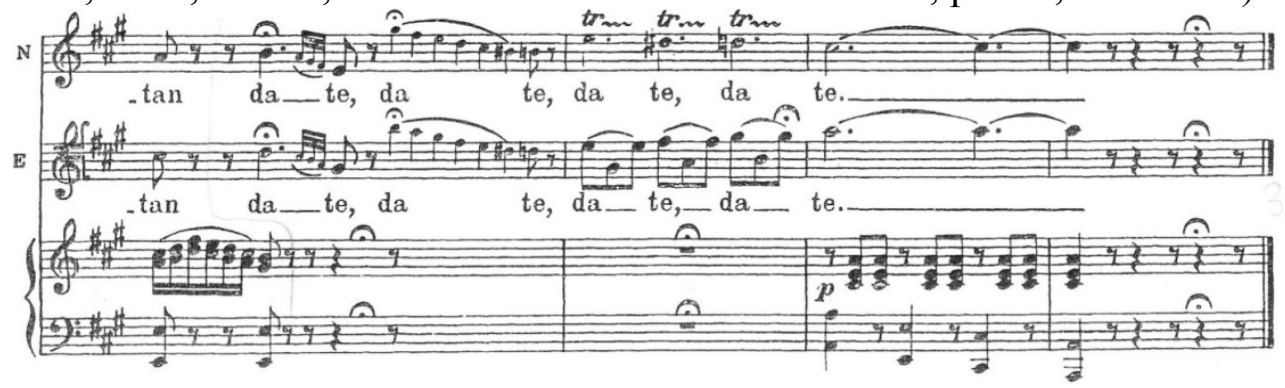

${ }^{100}$ Tell me you are mine(t.a.Cr.S.A.). 


\section{Conclusions}

The vocal and orchestral-instrumental virtuosity find in Donizetti a unique way of characters definition. The lyrical and comic moments are assembled with a lot of musical and dramatic imagination by exchanging replies, exclamations with the discrete support of the orchestra. Arias, duets, recitatives and ensembles make up a continuous stream of musical delight in a skillful and inspirational orchestration.

\section{References}

1. Celetti, R. - Il vocalissimo italiano da Rossini a Donizetti, Histoire de la Musique, Encyclopedie de la Pleiade, vol. II, Gallimard P.H., Paris, 1963

2. Constantinescu G. - Ghid de operă, Musical P.H., Bucharest, 1971

3. Constantinescu G., Caraman-Fotea D., G Constantinescu Gr., Sava I.- Ghid de operă, Composers Union Musical P.H., Bucharest, 1971

4. Constantinescu G.- Splendorile operei, Dicţionar de teatru liric, Didactic and Pedagogic P.H., Bucharest, 1995

5. Hodeir A. - Formele muzicii, Grafoart P.H., Bucharest, 2007

6. Negrea N. - Cartea spectatorului de operă, Composers Union Musical P.H., Bucharest, 1958

7 *** - Britannica Universal Encyclopedia, vol. V: D-E, Litera Publishing House, Bucharest, 201 